\title{
Initial Field Test of High-Energy \\ Corona Process for Treating a \\ Contaminated Soil-Offgas \\ Stream
}
R.R. Shah
R.E. Garcia
J.T. Jeffs
J.W. Virden
W.O. Heath

April 1995

Prepared for the U.S. Department of Energy under Contract DE-AC06-76RLO 1830

Pacific Northwest Laboratory Operated for the U.S. Department of Energy by Battelle Memorial Institute 


\title{
DISCLAIMER
}

This report was prepared as an account of work sponsored by an agency of the United States Government. Neither the United States Government nor any agency thereof, nor Battelle Memorial Institute, nor any of their employees, makes any warranty, expressed or implied, or assumes any legal liability or responsibility for the accuracy, completeness, or usefulness of any information, apparatus, product, or process disclosed, or represents that its use would not infringe privately owned rights. Reference herein to any specific commercial product, process, or service by trade name, trademark, manufacturer, or otherwise does not necessarily constitute or imply its endorsement, recommendation, or favoring by the United States Government or any agency thereof, or Battelle Memorial Institute. The views and opinions of authors expressed herein do not necessarily state or reflect those of the United States Government or any agency thereof.

\author{
PACIFIC NORTHWEST LABORATORY \\ operated by \\ BATTELLE MEMORIAL INSTITUTE \\ for the \\ UNITED STATES DEPARTMENT OF ENERGY \\ under Contract DE-AC06-76RLO 1830
}

Printed in the United States of America

Available to DOE and DOE contractors from the

Office of Scientific and Technical Information; P.O. Box 62, Oak Ridge, TN 37831; prices available from (615) 576-8401. FTS 626-8401.

Available to the public from the National Technical Information Service,

U.S. Department of Commerce, 5285 Port Royal Rd., Springfield, VA 22161. 
PNL-9224

UC-800

\section{Initial Field Test of High-Energy \\ Corona Process for Treating a Contaminated Soil-Offgas Stream}

R. R. Shah

R. E. Garcia

J. T. Jeffs

J. W. Virden

W. O. Heath

April 1995

Prepared for

the U.S. Department of Energy

under Contract DE-ACO6-76RLO 1830

Pacific Northwest Laboratory Richland, Washington 99352 
. 


\begin{abstract}
In May 1993, Pacific Northwest Laboratory's High Energy Corona (HEC) process was demonstrated on a pilot scale at the Savannah River Site for treating a soil offgas stream contaminated with $670 \pm 55$ ppmv perchloroethylene (PCE), $100 \pm 9.0$ ppmv trichloroethylene (TCE), and trace concentrations of trichloroethane. The process was tested at treatment rates from 1.4 to $42 \mathrm{cfm}$, corresponding to residence times of 15.7 to $0.8 \mathrm{~s}$. All systems functioned correctly, enabling the field demonstration to be completed ahead of schedule.

In the field, TCE destruction was greater than $99 \%$ for all cases except $0.8 \mathrm{~s}$ and PCE destruction ranged between $73 \%$ to greater than $99 \%$. On a carbon mass basis, all organic byproducts represented less than $4.2 \%$ of the total inlet carbon in TCE and PCE at the shortest residence time of $0.8 \mathrm{~s}$. Prior to the field-test a prototype HEC reactor was characterized in the laboratory under expected conditions over reactor residence times between 0.8 to $3.1 \mathrm{~s}$. For an inlet mixture of PCE and TCE, TCE destruction remained at or near $99 \%$ whereas PCE destruction ranged from $65 \%$ to $69 \%$. Thus, destruction efficiencies measured in the field generally exceeded those measured in the laboratory. The power requirements were also $14 \%$ to $34 \%$ lower in the field than in the laboratory.

Based on field performance data, coupled with engineering scaleup assumptions, the annual costs for HEC would be projected to be between four and six times lower than for catalytic oxidation at offgas treatment rates between 300 and $500 \mathrm{cfm}$, respectively at PCE and TCE combined concentrations at 3000 ppmv. Compared to commonly quoted costs for treatment using activated carbon ( $\$ 15$ to $\$ 30 / 1 b$ of contaminant), HEC would be projected to be between 10 and 50 times less expensive, within the range of stream fiowrates and contaminant concentrations used in the preliminary cost analysis.
\end{abstract}




\section{Acknowledgments}

The authors wish to thank John Haselow and his team at Westinghouse Savannah River Company (WSRC) for their outstanding technical support and hospitality that made our first field test possible and enjoyable. We also appreciate the early commitment made to the High Energy Corona technology by the U.S. Department of Energy's Office of Technology Development led by Dr. Clyde Frank, and the Volatile Organic Compound (VOC)-Nonarid Integrated Demonstration coordinated by Terry Walton of WSRC. We would also like to thank Steven Stein and Thomas Brouns of the VOC-Arid Integrated Demonstration for their encouragement and support, and interest in seeing the HEC technology move forward into commercial applications. We are grateful for the efforts of Susan Bauer in our Public Relation's Office, Paul Zimmerman in our Patent Office, and Marv Clement in our Technology Transfer Office. They have been a catalyst for private-sector interest in the HEC technology. We thank Theresa Bergsman for her assistance in the economic-analysis section of this report, and for her active role in initiating and directing a new Research and Development program at Pacific Northwest Laboratories (PNL) that is focusing on a more fundamental understanding of the chemistry and physics associated with low-temperature plasmas. We would like to extend special thanks to Mike Miller for his support on power system acquisition, electrical measurements, and pragmatic design suggestions. We also would like to thank Barry Hayden, Dave Anderson, Ron Moore, Boyd Champion, and Gary Mong for their advice and assistance in byproduct analysis. The authors also thank Rex Bogart for his skill in designing the HEC field system, and the team of craftmen who constructed it, with special thanks to Jack Irwin, Louis Hogan, Terry Mohar, Jim Sullivan, and Gary Fisher. Finally, we appreciate PNL's commitment to integrity and meeting client's needs as exemplified by our department manager, Dr. Harry Burkholder. 


\section{Contents}

1.0 Background and Introduction $\ldots \ldots \ldots \ldots \ldots \ldots \ldots \ldots \ldots \ldots \ldots \ldots \ldots$

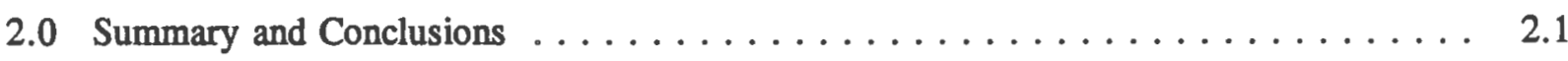

2.1 Laboratory Development and Testing . . . . . . . . . . . . 2.1

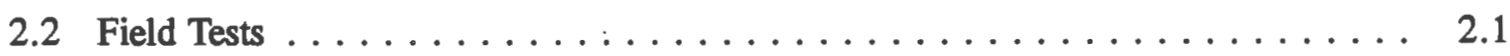

2.3 Projected Treatment Costs in Comparison with Catalytic

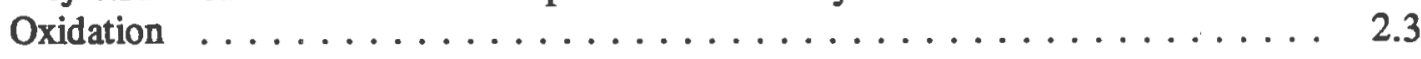

3.0 Description of Reactors and Field Process $\ldots \ldots \ldots \ldots \ldots \ldots \ldots \ldots \ldots \ldots$

3.1 High-Energy Corona Reactors $\ldots \ldots \ldots \ldots \ldots \ldots \ldots \ldots \ldots \ldots \ldots \ldots$

3.2 Mobile Test Facility $\ldots \ldots \ldots \ldots \ldots \ldots \ldots \ldots \ldots \ldots \ldots \ldots \ldots \ldots$

3.3 Field Instrumentation $\ldots \ldots \ldots \ldots \ldots \ldots \ldots \ldots \ldots \ldots \ldots$

3.4 Humidity Control System $\ldots \ldots \ldots \ldots \ldots \ldots \ldots \ldots \ldots \ldots$

4.0 Laboratory Development and Testing $\ldots \ldots \ldots \ldots \ldots \ldots \ldots \ldots \ldots \ldots$

4.1 Laboratory Destruction Efficiencies $\ldots \ldots \ldots \ldots \ldots \ldots \ldots \ldots \ldots \ldots$

4.2 Laboratory Byproduct Formation $\ldots \ldots \ldots \ldots \ldots \ldots \ldots \ldots \ldots$

5.0 Field Tests $\ldots \ldots \ldots \ldots \ldots \ldots \ldots \ldots \ldots \ldots \ldots \ldots \ldots \ldots \ldots \ldots \ldots$

5.1 Demonstration Site History and Field Conditions $\ldots \ldots \ldots \ldots \ldots \ldots$

5.2 Analytical Techniques Used for Field Testing $\ldots \ldots \ldots \ldots \ldots \ldots \ldots$

5.3 Effect of Inlet Humidity on HEC Performance During Preoperational Tests . . . . 5.4

5.4 Effect of Reactor Residence Time on HEC Performance During Preoperational Tests . . . . . . . . . . . . . . . . . . . . . . 5

5.5 Destruction Efficiencies for Trichloroethylene Measured During Offgas Treatment Tests . . . . . . . . . . . . . . . . . 5.7

5.6 Destruction Efficiencies for Perchloroethylene Measured During Offgas Treatment Tests . . . . . . . . . . . . . . . $5 \ldots \ldots$ 
5.7 Comparison Between On-Line and Off-Line Determination of Destruction

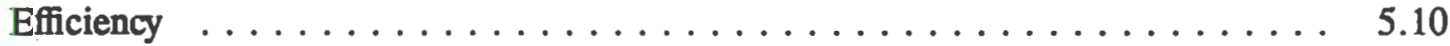

5.8 Byproduct Formation During Treatment of Soil Offgas . . . . . . . . 5.10

5.9 Effect of Reactor Bank on Destruction of PCE and TCE in Soil Offgas . . . . . 5.12

6.0 Projected Treatment Costs in Comparison with Catalytic Oxidation $\ldots \ldots \ldots \ldots .6 .1$

6.1 Scaleup of HEC Reactor $\ldots \ldots \ldots \ldots \ldots \ldots \ldots \ldots \ldots \ldots \ldots \ldots \ldots \ldots \ldots \ldots$

6.2 Capital Costs for a Full-Scale HEC Process $\ldots \ldots \ldots \ldots \ldots \ldots \ldots \ldots .2$

6.3 Annual Costs for a Full-Scale HEC Process $\ldots \ldots \ldots \ldots \ldots \ldots \ldots \ldots .3$

6.4 Capital Costs for a Full-Scale CO Process . . . . . . . . . . . . 6.4

6.5 Annual Costs for a Full-Scale CO Process . . . . . . . . . . . . 6.4

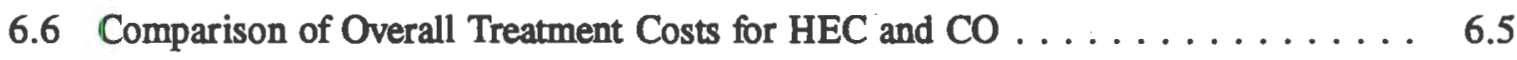

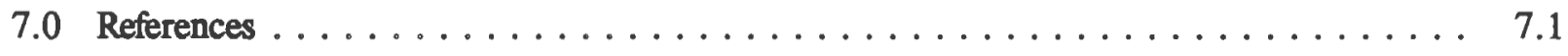




\section{Figures}

3.1 Reactor Outlet and Electrode Connections $\ldots \ldots \ldots \ldots \ldots \ldots \ldots \ldots \ldots . \ldots \ldots . \ldots \ldots$

3.2 Exterior View of Mobile Test Facility $\ldots \ldots \ldots \ldots \ldots \ldots \ldots \ldots \ldots \ldots . \ldots \ldots$

3.3 Reactor Skid as Viewed from the Control Room . . . . . . . . . . . 3.5

3.4 Process Flowsheet $\ldots \ldots \ldots \ldots \ldots \ldots \ldots \ldots \ldots \ldots \ldots \ldots \ldots \ldots \ldots . \ldots \ldots \ldots$

3.5 Reactor Pressure Drop Versus Flow . . . . . . . . . $\ldots \ldots \ldots \ldots \ldots$

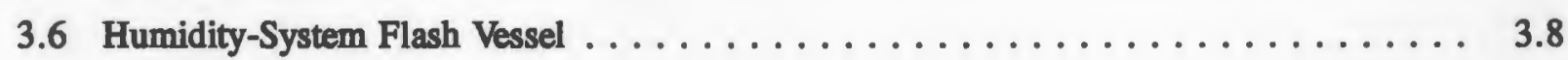

5.1 Schematic Design of Savannah River's ISAS System $\ldots \ldots \ldots \ldots \ldots \ldots \ldots .3$

5.2 Effect of Inlet Humidity on High-Energy Corona Power $\ldots \ldots \ldots \ldots \ldots \ldots . . \ldots$

5.3 Steady State Destruction Efficiencies for Trichloroethylene in Soil Offgas $\ldots \ldots \ldots \quad 5.7$

5.4 Steady State Destruction Efficiencies for Perchloroethylene in Soil Offgas . . . . . . 5.9

5.5 Startup Destruction Efficiencies for Perchloroethylene in Soil Offgas $\ldots \ldots \ldots \ldots .5 .9$

5.6 Effect of Residence Time on Byproduct Distributions from Offgas Treatment ..... 5.11

5.7 Effect of Reactor Bank on Perchloroethylene Destruction $\ldots \ldots \ldots \ldots \ldots \ldots . \ldots \ldots$ 


\section{Tables}

2.1 Comparison of HEC Performance in the Field and Laboratory $\ldots \ldots \ldots \ldots$

2.2 Comparison of Treatment Costs for HEC and Catalytic Oxidation $\ldots \ldots \ldots \ldots$

4.1 Energy Requirement per Pound of Contaminant Treated . . . . . . . . . . . 4.2

4.2 Observed Destruction Efficiencies of TCE/PCE $\ldots \ldots \ldots \ldots \ldots \ldots \ldots$

4.3 Byproduct Concentrations for Trichloroethylene (TCE) $\ldots \ldots \ldots \ldots \ldots \ldots$

4.4 Byproduct Concentrations for Perchoroethylene (PCE) $\ldots \ldots \ldots \ldots \ldots \ldots \ldots$

4.5 Byproduct Concentrations for Mixture of PCE and TCE $\ldots \ldots \ldots \ldots \ldots$

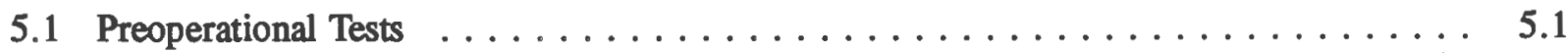

5.2 Offgas Treatment Tests $\ldots \ldots \ldots \ldots \ldots \ldots \ldots \ldots \ldots \ldots \ldots \ldots \ldots$

5.3 Variation in TCE/PCE Detection Between $5 / 9$ and $5 / 13 / 93 \ldots \ldots \ldots \ldots \ldots$

5.4 Effect of Inlet Humidity on Destruction of Pure TCE $\ldots \ldots \ldots \ldots \ldots$

5.5 Effect of Inlet Humidity on Byproduct Formation $\ldots \ldots \ldots \ldots \ldots \ldots$

5.6 Effect of Residence Time on Destruction of Pure TCE $\ldots \ldots \ldots \ldots \ldots$

5.7 Electrical Requirements and Costs for Destruction of Pure Trichloroethylene Treatment . . . . . . . . . . . . . . 5.7

5.8 Percentage of Byproduct Organic Carbon $\ldots \ldots \ldots \ldots \ldots \ldots \ldots \ldots \ldots$

5.9 Effect of Reactor Bank on Process Performance $\ldots \ldots \ldots \ldots \ldots \ldots \ldots$

6.1 Summary of HEC Capital Investment Costs $\ldots \ldots \ldots \ldots \ldots \ldots$

6.2 Summary of HEC Operating and Total Annual Costs $\ldots \ldots \ldots \ldots . \ldots$

6.3 Summary of Catalytic Oxidation Capital Investment Costs $\ldots \ldots \ldots \ldots . \ldots . \ldots$

6.4 Summary of Catalytic Oxidation Operating and Total Annual Costs $\ldots \ldots \ldots . \ldots$

6.5 Comparison of Treatment Costs for HEC and Catalytic Oxidation $\ldots \ldots \ldots 6$ 



\subsection{Background}

The High-Energy Corona (HEC) technology for treating process offgases has been under development at Pacific Northwest Laboratory (PNL) ${ }^{(a)}$ since 1991. The HEC process uses high-voltage electrical discharges in air to ionize the air, forming a low-temperature plasma that would be expected to destroy a wide variety of organic compounds in air. The plasma contains strong oxidants, possibly including hydroxyl radicals, hydroperoxy radicals, superoxide radicals, various excited as well as ionized forms of oxygen, high-energy electrons, and ultraviolet (UV) light. Because the high-voltage plasma is produced near ambient temperatures and pressures, yet exhibits extremely rapid destruction kinetics with relatively low power requirements, the HEC technique appears promising as a low-cost treatment technique (Virden et al. 1992).

As part of the Volatile Organic Compound (VOC) Nonarid Integrated Demonstration (ID) at the DOE Savannah River Site, research activities were initiated in December 1991 to develop a prototype HEC process for a small-scale field demonstration to treat a soil-offgas stream contaminated with trichloroethylene (TCE) and perchloroethylene (PCE) at varying concentrations. Over an 18-month period, the HEC technology was developed on a fast track, through bench and pilot scales into a trailer-mounted system that was tested at the Nonarid ID. Other national laboratories, universities, and private companies have also participated at the Nonarid ID to demonstrate a number of conventional, emerging and innovative approaches for treating the same soil-offgas stream.

The initial HEC field demonstration at the Nonarid ID had two main objectives. The first was to characterize the performance of the HEC process in terms of contaminant destruction efficiency and byproduct formation. The second objective was to collect sufficient field data to project the technical and economic merits of a full-scale HEC treatment unit. A critical subtask, of course, was to determine whether the HEC technology could function as well under field conditions as in the laboratory.

The majority of this work was funded by the VOC Nonarid ID with funding for the field equipment provided by the VOC Arid ID at the Hanford Site in Washington. Both Integrated Demonstrations are supported by the U.S. Department of Energy's Office of Technology Development.

(a) Pacific Northwest Laboratory is operated for the U.S. Department of Energy by Battelle Memorial Institute under Contract DE-AC06-76RLO 1830. 



\subsection{Summary}

From May 2 through May 19, 1993, PNL's HEC process was demonstrated on a pilot scale for treating soil offgases contaminated with chlorinated solvents from a soil-vapor extraction vent at the Savannah River Site 3/700 Area. The contaminants included $670 \pm 55$ ppmv PCE and $100 \pm 9.0 \mathrm{ppmv}$ TCE. Trace concentrations of trichloroethane were also present. The pilot-scale system was operated at flow rates from $1.4 \mathrm{cfm}$ up to $42 \mathrm{cfm}$ using three banks of HEC reactors configured in parallel. All systems functioned correctly, enabling the field demonstration to be completed ahead of schedule.

\subsection{Laboratory Development and Testing}

Before field-testing the process, characterization tests were performed in the laboratory using a single, prototype reactor operated under expected field conditions. These tests indicated the destruction of TCE at $99 \%$ efficiency over three reactor residence times ranging from 0.8 to $3.1 \mathrm{~s}(0.5$ to $2.0 \mathrm{cfm})$. Destruction of PCE increased from $58 \%$ to $85 \%$ over the same residence times. When mixed with TCE to simulate field conditions, PCE destruction ranged from $65 \%$ to only $69 \%$, whereas TCE destruction remained at or near $99 \%$.

The primary decomposition products of TCE were dichloroacetylchloride and pentachloroethane, with concentrations dependent on reactor residence time. At an inlet concentration of $920 \mathrm{ppmv}$ TCE, outlet concentrations were $8 \mathrm{ppmv}$ dichloroacetylchloride and $6 \mathrm{ppmv}$ pentachloroethane at a typical residence time of $1.6 \mathrm{~s}$. The decomposition products of pure PCE were similar to those of TCE, but concentrations of dichloroacetylchloride were $1 \mathrm{ppmv}$ or less, pentachloroethane was below detection limits, and hexachloroethane was detected at 4 ppmv. Byproduct distributions for laboratory tests with representative mixtures of TCE and PCE were essentially a combined total of the single-component tests. In most of the laboratory tests, phosgene was detected in the reactor effluent but could not be quantified. Likewise, trace amounts of chloroform (below 1 ppmv) were detected in all of the samples.

\subsection{Field Tests}

A total of 15 tests were performed in the field to obtain data on 1) the ability of the HEC process to treat a soil offgas stream contaminated with a mixture of PCE and TCE, 2) the effect of inlet humidity on the performance of the process, and 3) the projected treatment costs. Of the 15 tests, seven were performed on the actual soil offgas stream, and eight preoperational tests were performed using a simulated offgas stream containing only TCE in humid air.

As illustrated in Table 2.1, for the tests with actual soil offgas, TCE destruction was greater than $99 \%$ for all cases except the $0.8 \mathrm{sec}$. PCE destruction ranged between $73 \%$ to greater than $99 \%$. In most cases, destruction efficiencies measured in the field exceeded those measured in the laboratory. The power required to achieve these destruction efficiencies was also 14 to $34 \%$ lower in the field than in the laboratory on a power-per-reactor basis. 
Table 2.1. Comparison of HEC Performance in the Field and Laboratory

\begin{tabular}{|c|c|c|c|c|}
\hline \multirow{2}{*}{$\begin{array}{l}\text { Residence Time } \\
\qquad(\mathrm{sec})\end{array}$} & \multicolumn{2}{|c|}{ Laboratory Destruction } & \multicolumn{2}{|c|}{ Field Destruction $^{(a)}$} \\
\hline & PCE & TCE & PCE & TCE \\
\hline 0.8 & 64.6 & 98.6 & 73.3 & 95.1 \\
\hline 1.6 & 62.8 & 98.4 & 75.6 & $\geq 99^{(b)}$ \\
\hline 3.1 & 69.4 & $\geq 99$ & 94.0 & $\geq 99$ \\
\hline $15.7^{(\mathrm{c})}$ & N/A & N/A & $\geq 99^{\text {(d) }}$ & $\geq 99^{\text {(d) }}$ \\
\hline
\end{tabular}

(a) Destruction is based on effluent analysis by WSRC

(b) Destruction efficiency for the overall process was $97.5 \%$ because one reactor bank was operated at reduced voltage. The other two reactor banks yielded $>99 \%$ destruction.

(c) The 15.7-s test was conducted with two banks operating. The other residence time tests had operated three reactor banks.

(d) Based on PNL online effluent measurement; a sampling error occurred with WSRC analysis.

Based on off-line effluent analyses performed by WSRC, the main differences between laboratory and field operations were increased amounts of chloroform and carbon tetrachloride at concentrations between 5-10 ppmv, and an apparent lack of dichloroacetylchloride (DCAC), which was the main TCE-destruction byproduct detected in the laboratory. Phosgene was measured indirectly as a derivatized compound in the 4-10 ppmv range. Other byproducts, detected in concentrations below 3 ppmv, were trichloroacetylaldehyde, pentachloroethane, hexachloroethane, and possibly trichloronitromethane. On a carbon mass basis, all organic byproducts represented less than $4.2 \%$ of the total inlet carbon in TCE and PCE at a nominal residence time of $0.8 \mathrm{sec}$.

The field system included provisions for adjusting the humidity of the inlet stream as required to achieve optimum performance. Preoperational field tests (conducted using pure TCE in a simulated offgas) showed that the main effect of increasing the humidity upstream of the HEC process was an increase in the levels of partially reacted byproducts in the reactor effluent. Somewhat unexpectedly, increases in humidity [from $45 \%$ to $90 \%$ relative humidity (R.H.)] resulted in less than a $10 \%$ increase in power, and had a negligible effect on destruction efficiency. Based on these findings, subsequent demonstration tests performed on the actual soil offgas were conducted without adjusting the inlet humidity, which generally remained stable at $40 \%$ to $48 \%$ R.H.

The preoperational tests also showed that not all of the reactor banks performed equally well. This was confirmed during the subsequent tests with soil offgas. In one case, one of the reactor banks achieved only $93.5 \%$ destruction of TCE while the other two achieved $99 \%$. The one offending reactor bank effectively lowered the performance of the overall system to $97 \%$ destruction (as shown in Table 2.1). The offending bank was observed to exhibit relatively violent sparking behavior that, for the test conducted at a residence time of $1.6 \mathrm{~s}$, required the power-supply voltage to be lowered from $30 \mathrm{kV}$ to $27 \mathrm{kV}$. Oddly, the byproduct levels in the overall process effluent produced during this test 
were drastically reduced, possibly suggesting that the sparking reactor bank, operated at full voltage during most of the field tests, was responsible for creating a disproportionate amount of partially reacted byproducts in the overall process effluent.

\subsection{Projected Treatment Costs in Comparison with Catalytic Oxidation}

Based on a preliminary analysis, the projected annual costs for HEC would be between four and six times lower than for catalytic oxidation at offgas treatment rates between 300 and $500 \mathrm{cfm}$, respectively. This is based on a soil-offgas stream contaminated with PCE and TCE at a combined concentration of 3000 ppmv. For comparison, the annual cost of HEC for treating the same stream volumes at a total contaminant loading of 1000 ppmv would be roughly half the cost of catalytic oxidation. Because the preliminary cost analysis for a full-scale HEC process reflects a relatively large number of technical assumptions, the projected costs listed in Table 2.2 include a 25\% contingency.

Compared to commonly quoted costs for treatment using activated carbon ( $\$ 15$ to $\$ 30 / \mathrm{lb}$ of contaminant), HEC would be projected to be between 10 and 50 times less expensive, within the range of stream flowrates and contaminant concentrations used in the preliminary cost analysis. The costs associated with HEC assume a secondary wet scrubber to remove and neutralize hydrochloric acid, enabling the HEC process to meet existing regulatory requirements for clean air. The scrub solution is assumed to be disposable on-site as an unregulated (Class D) aqueous waste, at a total volume of between 1,000- and 3,000-gal/year. These values depend on the flowrate and concentration of the stream being treated and a disposal cost (for handling and record keeping) of between $\$ 2$ and . $\$ 10 \mathrm{~K}$ per year.

Table 2.2. Comparison of Treatment Costs for HEC and Catalytic Oxidation

\begin{tabular}{|c|c|c|c|c|}
\hline \multirow[b]{2}{*}{ Treatment Technology } & \multicolumn{2}{|c|}{$300 \mathrm{cfm}$ inlet } & \multicolumn{2}{|c|}{$500 \mathrm{cfm}$ inlet } \\
\hline & $\begin{array}{c}1000 \mathrm{ppmv} \\
(\$ / \mathrm{lb})\end{array}$ & $\begin{array}{c}3000 \text { ppmv } \\
(\$ / \mathrm{lb})\end{array}$ & $\begin{array}{c}1000 \text { ppmv } \\
(\$ / 1 \mathrm{lb})\end{array}$ & $\begin{array}{c}3000 \text { ppmv } \\
(\$ / l b)\end{array}$ \\
\hline High-Energy Corona & 1.50 & 0.50 & 1.40 & 0.50 \\
\hline Catalytic Oxidation & 3.40 & $3.40^{(\mathrm{a})}$ & 3.10 & $3.10^{(\mathrm{a})}$ \\
\hline
\end{tabular}

(a) Catalytic Oxidation systems do not operate above $1000 \mathrm{ppmv}$. Therefore, treatment of a $3000 \mathrm{ppmv}$ stream would require a 2:1 dilution resulting in roughly the same operating and capital costs as the treatment at $1000 \mathrm{ppmv}$. 



\subsection{Description of Reactors and Field Process}

\subsection{High-Energy Corona Reactors}

The HEC reactor design used in both laboratory and field tests was developed in 1993, based on the results of earlier work at PNL described by Virden et al. (1992). The reactors consisted of nonconductive tubes configured with a central high-voltage electrode, a grounded outer surface, and inlet and outlet gas connections. The reactors used the same packed-bed material and geometry for plasma generation as described by Virden et al. (1992). The packed-bed volume was $226 \mathrm{in}^{3}$, with a 1/4-in. stainless steel (type 304) rod used as the high-voltage electrode. Figure 3.1 is a photograph of the gasstream outlets and high-voltage electrode connections for a bank of reactors used in the field process.

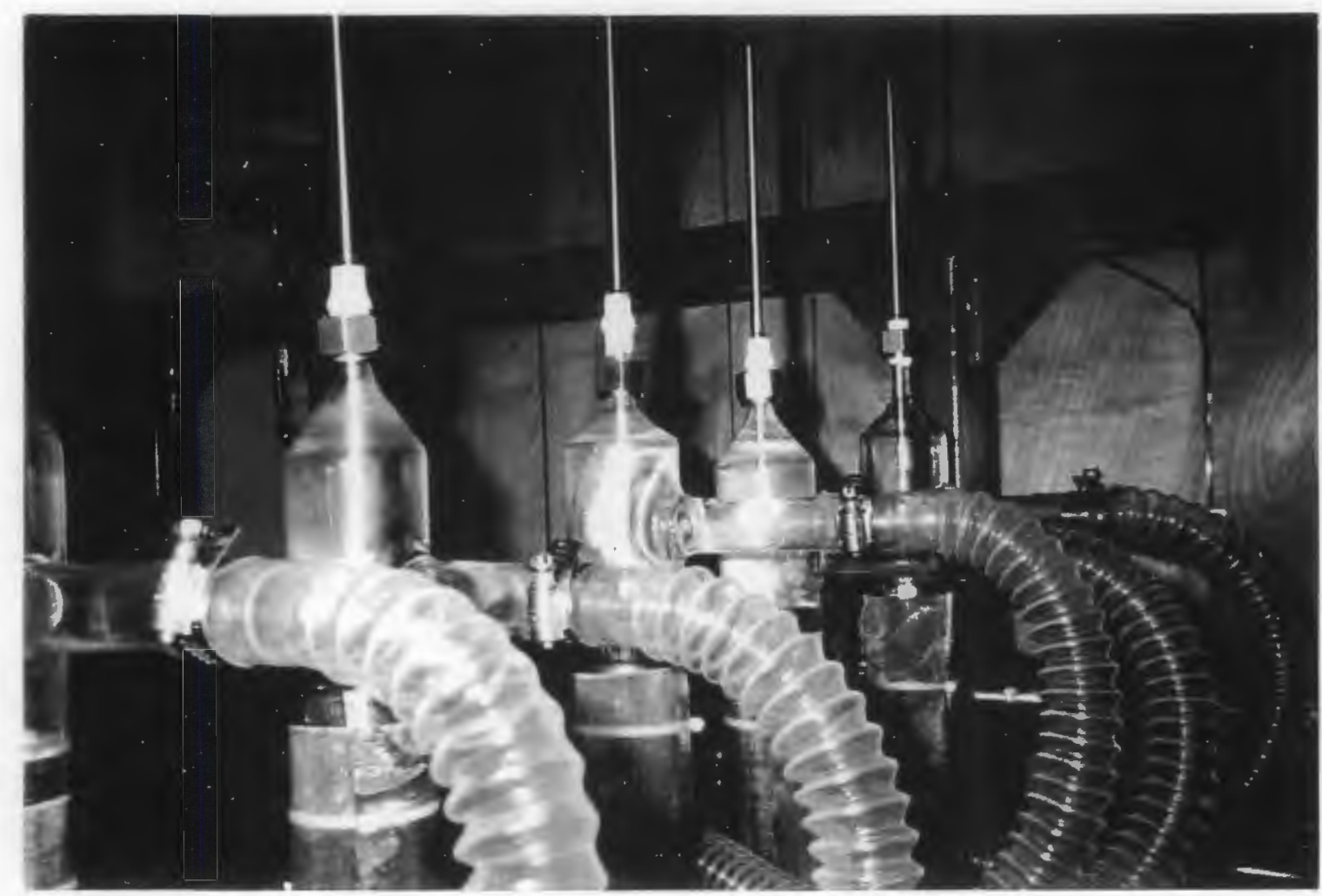

Figure 3.1. Reactor Outlet and Electrode Connections 



\subsection{Mobile Test Facility}

The field test system was housed in a conventional mobile office trailer with two rooms, each with a separate ventilation system. An exterior view of the trailer is shown in Figure 3.2. The control room, located in the front of the trailer, was equipped with a recirculating heat pump for temperature control, two windows, an exterior side door, and an interior door to the process room. The control room was used as the central location for flow and humidity control, reactor-flow bypass control, control of three high-voltage power supplies, acquisition of temperature, pressure, voltage, current, and humidity data, and housed an on-line gas chromatograph. Located at the rear of the trailer, the process room was equipped with a separate outside-air ventilation system, and a double-wide exterior door. The process room contained a reactor skid, three high-voltage transformers, and high-voltage electrical buswork.

All inlet and outlet piping (2-in. Schedule-40, type-304 stainless steel) was mounted in the process room on a removable skid that held $21 \mathrm{HEC}$ reactors. Figure 3.3 is a photograph of the reactor skid as viewed from the control room. The contaminated soil offgas was routed through three banks of reactors, with each bank containing seven corona reactors. All the reactors and banks were connected in parallel. Flow to the reactor banks could be bypassed with solenoid-activated control valves. A bypass switch for activating the solenoid valves was mounted in the control room. A process flowsheet is provided in Figure 3.4. The treated offgas stream exiting the HEC process was passed through an activated carbon system located outside the trailer to remove all byproducts and unreacted contaminants remaining in the offgas before atmospheric release. The carbon filter system was monitored and maintained by WSRC staff.

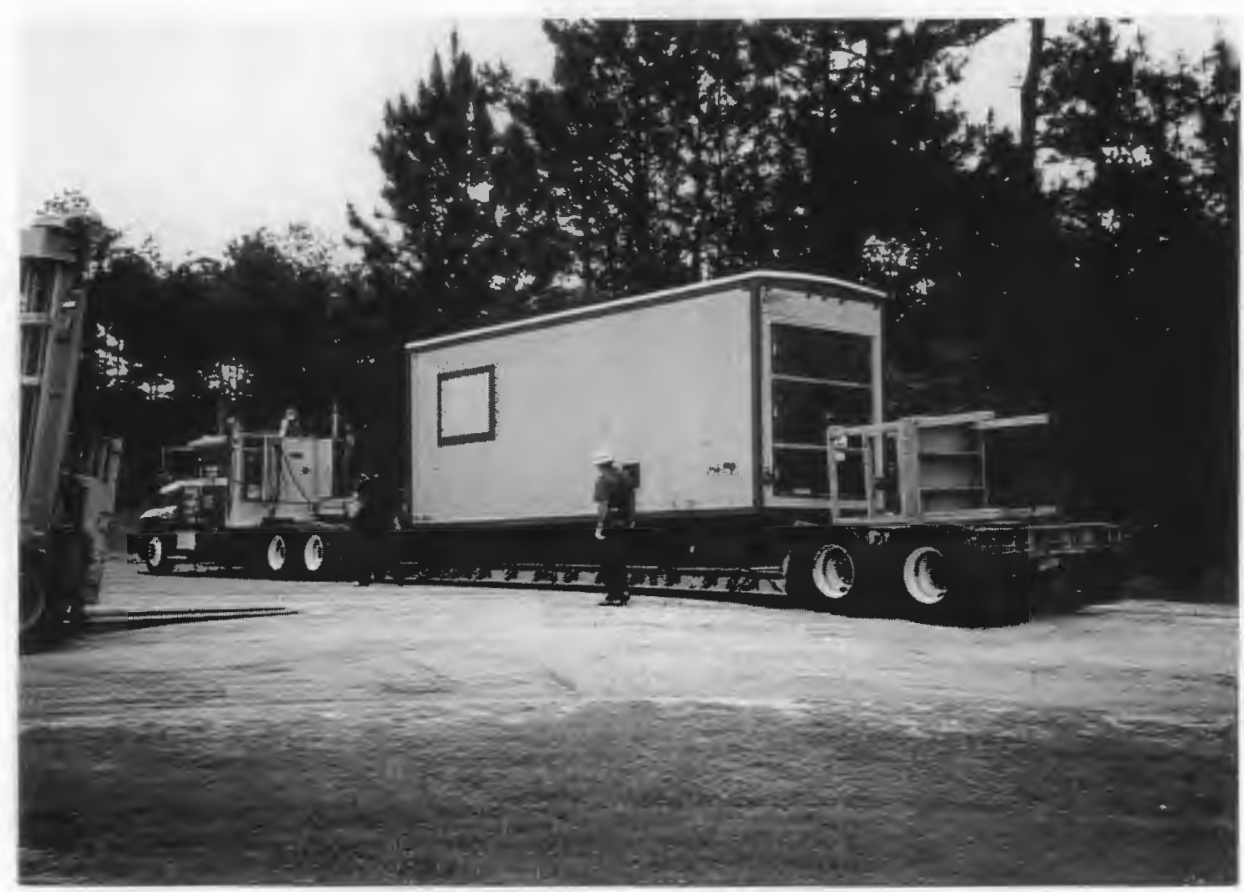

Figure 3.2. Exterior View of Mobile Test Facility 


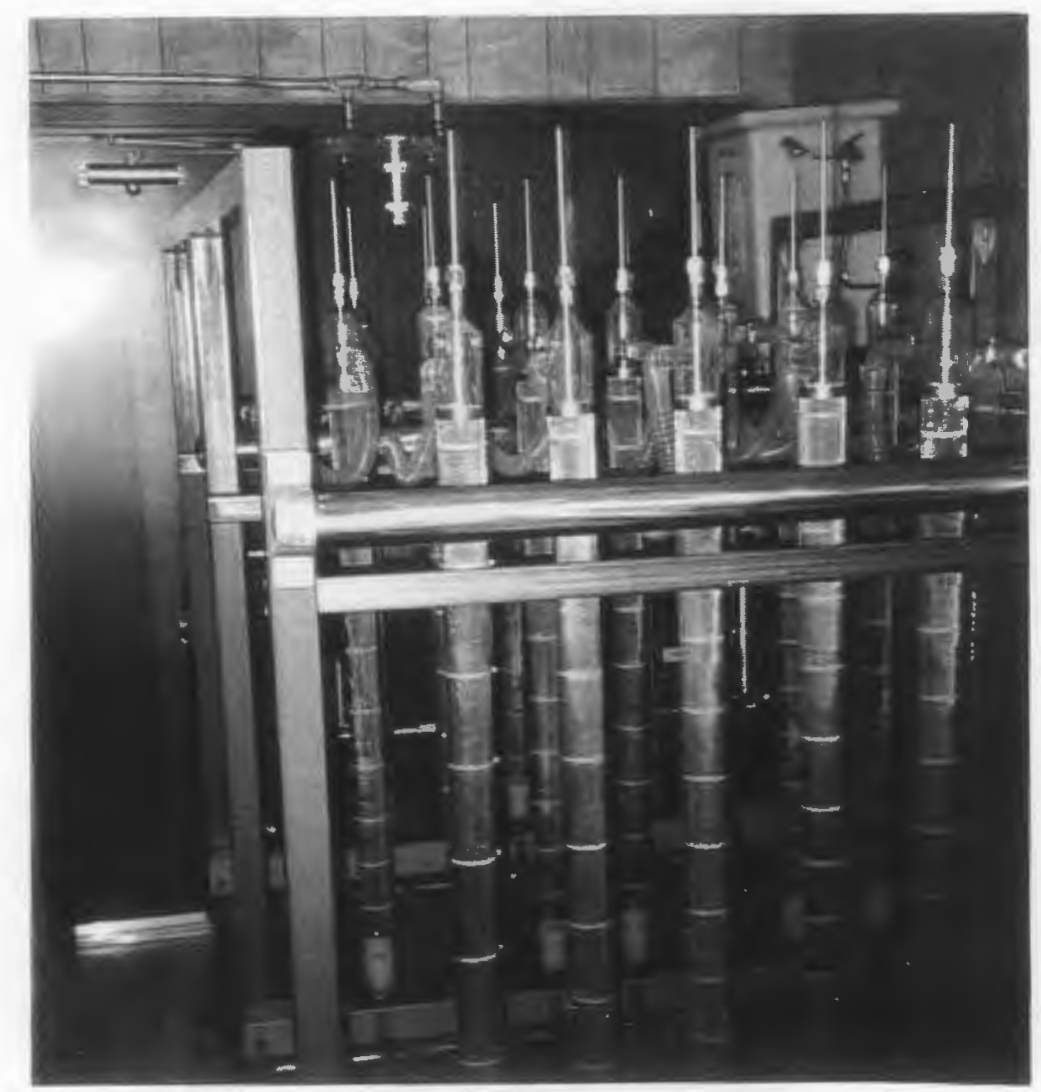

Figure 3.3. Reactor Skid as Viewed from the Control Room

To provide a contaminated air stream for preoperational verification tests, compressed air was bubbled through two gas-washing bottles containing pure liquid TCE and mixed into an uncontaminated air stream produced by a compressor. The level of contaminant in the stream was adjustable by adjusting the flowrate of compressed air through the gas-washing bottles. The flowrates were adjusted using a bank of rotometers.

Three separate high-voltage power supplies were used in the field-test system, with each connected to a separate bank of reactors. This approach afforded redundancy, with each system capable of exceeding the demonstration objective of 5- to 10-cfm treatment. The power supplies consisted of three high-voltage transformers located in the process room that were controlled with three independent control cabinets located in the control room. Each power supply provided variable voltage to $30-\mathrm{kV}$ at 7.5-kVA. For safety, the process room egress points (the exterior double-wide door and the interior door to the control room) were interlocked to all three control cabinets.

Electric service requirements for the field process were: $480-\mathrm{V}$, three-phase, $25-\mathrm{kVA}$, wired to three 480-V receptacles for the HV power supplies; and a separate single-phase feed for the trailer's 230/115-V, 100-A power panel. The power was supplied by a 37.5-kVA diesel generator operated 24-h/day. Other field-service requirements included a portable air compressor for preoperational and static-pressure testing, and compressed nitrogen and breathing-air cylinders for operating the gas chromatograph and process solenoid valves. 


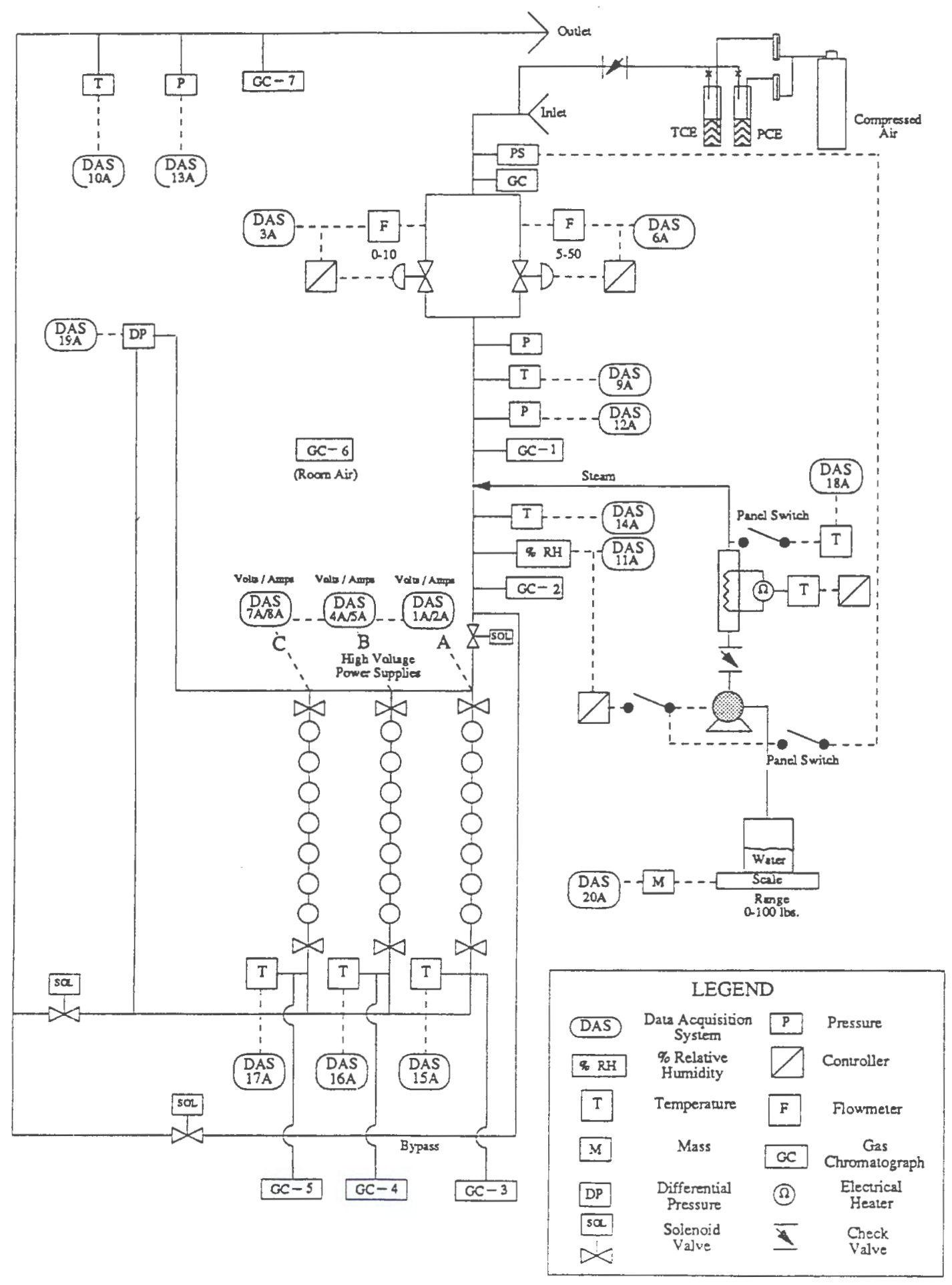

Figure 3.4. Process Flowsheet 


\subsection{Field Instrumentation}

Stream conditions were measured at the locations shown on the process flowsheet in Figure 3.4. Sensors included Type-T thermocouples for gas temperature, two WIKA 0-25 psia absolute-pressure transducers, a Validyne 0-35-in. W.C. differential pressure sensor, a Vaisala relative-humidity sensor and two Sierra mass-flow controllers. The two mass-flow controllers were used to measure and control the offgas flowrate at the process inlet. Inlet flow rates were controllable from 1 to $50 \mathrm{cfm}$ within two flow regimes $(1-10 \mathrm{~cm}$ and 5-50 cfm). The differential-pressure sensor was used to measure the total pressure drop across the reactor banks. Figure 3.5 shows the pressure drops measured across the reactors as a function of flowrate. The voltage and amperage associated with the secondary side of each of the three high-voltage power supplies were also measured using analog outputs from each of the power supplies. All measurements were automatically recorded on a real-time data acquisition system (DAS) using a data logger and an IBM computer.

A Hewlett-Packard 5890 Series II gas-chromatograph (GC) equipped with a flame ionization detector (FID) and a 12-port autosampler was used to provide an on-line indication of destruction efficiency and byproduct distributions. Contaminant samples were obtainable at the seven locations shown on the process flowsheet (Figure 3.4), including six on-line sample ports and one room-air sample port located in the process room. (A description of GC techniques used both in the laboratory and in the field is provided in Section 4.0.)

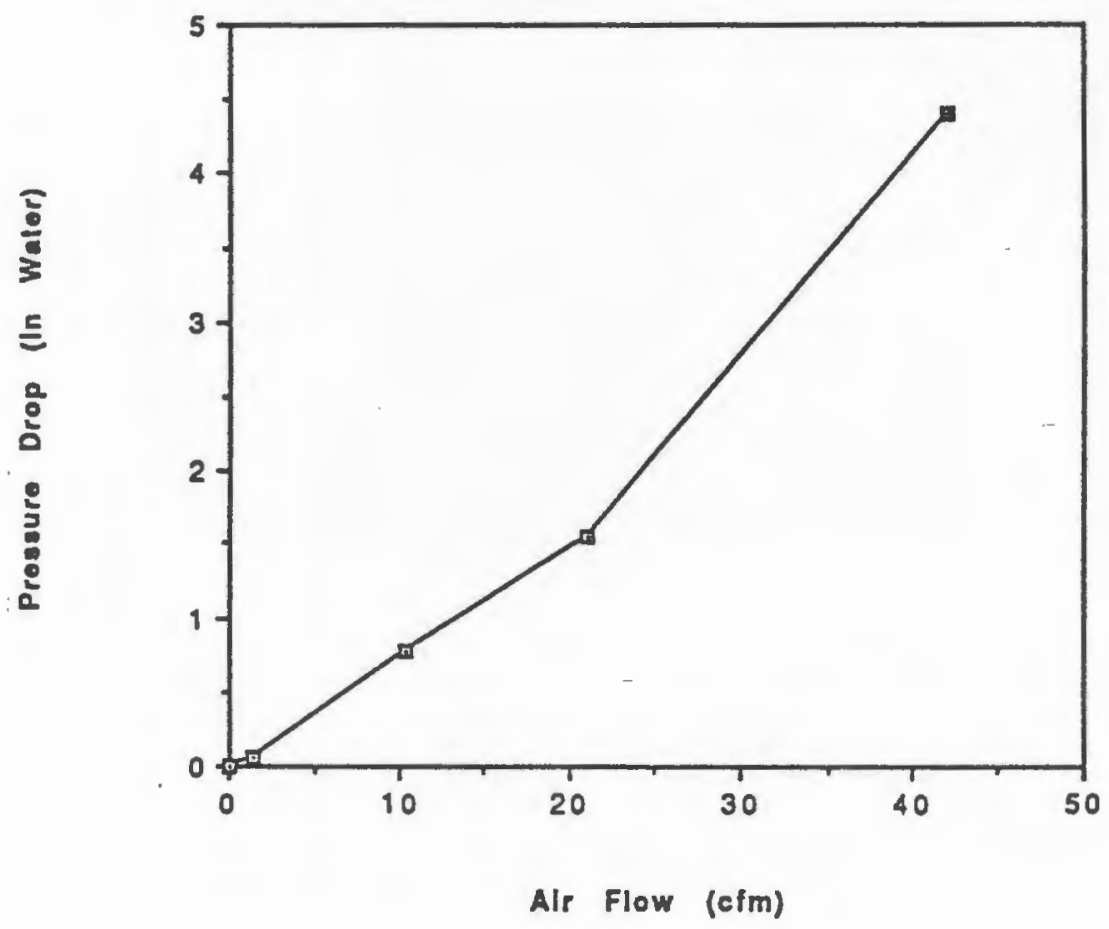

Figure 3.5. Reactor Pressure Drop Versus Flow 


\subsection{Humidity Control System}

A humidification system was provided to elevate and control the humidity of the inlet offgas stream as a means of controlling static charge accumulation and sparking in the HEC reactors. This system consisted of an externally controlled peristaltic pump, two PID controllers, the humidity sensor, and a $4-\mathrm{kW}$, electrically heated flash vessel contained in an insulated polyethylene tank. Figure 3.6 is a photograph showing the flash vessel (located near the skid at the rear of the trailer.) Distilled water was pumped into the flash vessel at a rate established either manually or using one of the PID controllers. The flash vessel was held at $350^{\circ} \mathrm{C}$ using the other PID controller connected to the 4-kW heater. On entering the heated vessel, the distilled water flashed into steam and exited the vessel through a lagged tube connected to the inlet stream.' A pressure-activated switch was used to automatically shut off the flow of distilled water to the flash vessel in the event that the offgas flow to the HEC process was shut off as by failure of the offgas blower. The cumulative amount of distilled water used was measured using a 100-lb mass scale with an analog output recorded by the DAS.

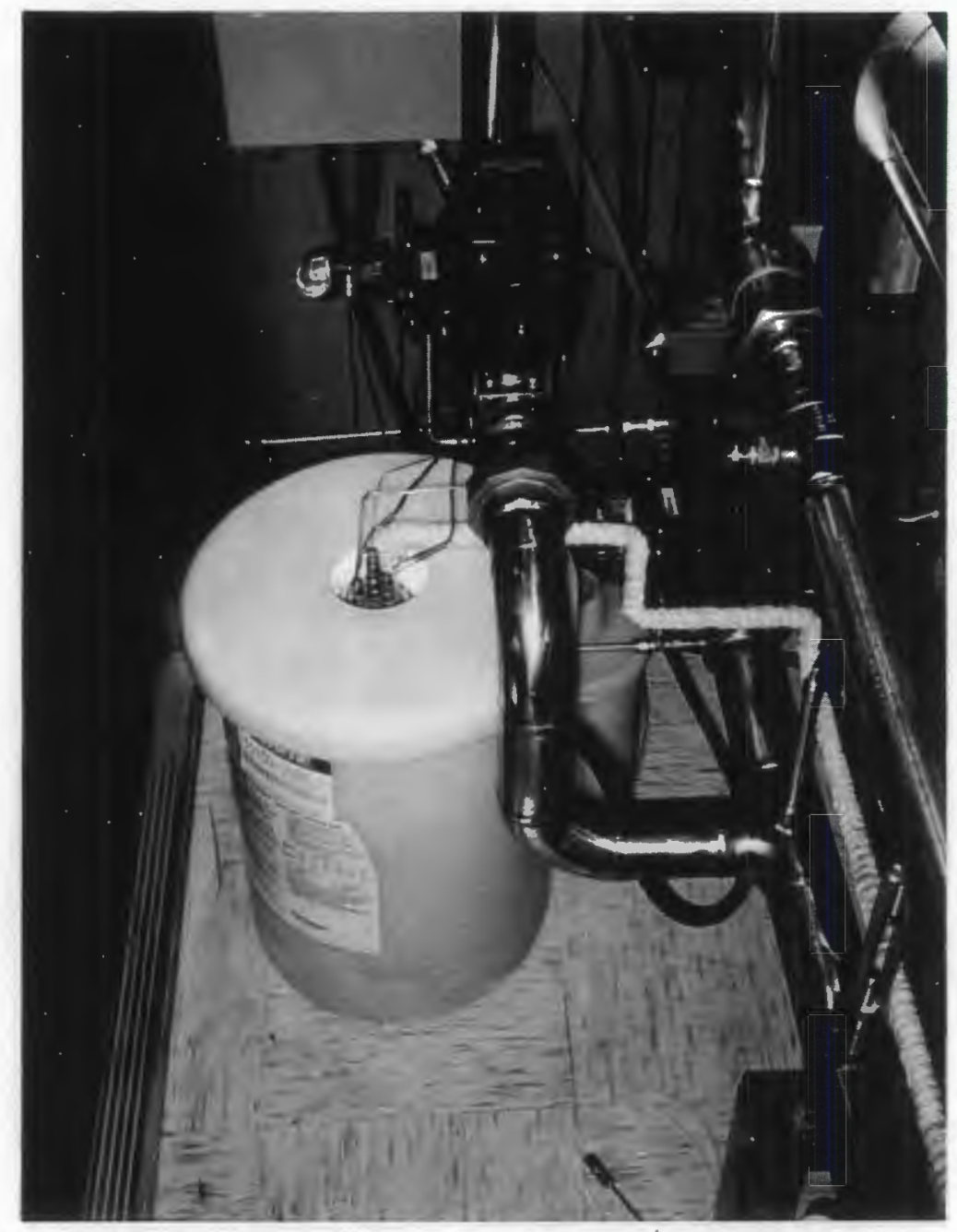

Figure 3.6. Humidity-System Flash Vessel 


\subsection{Laboratory Development and Testing}

Before field testing the HEC process, characterization tests were performed in the laboratory using a single, pilot-scale HEC reactor operated under expected field conditions. These tests characterized the laboratory performance of an HEC reactor in destroying perchloroethylene and trichloroethylene in humid air, and measured reaction byproducts to enable comparison with field performance. All tests were performed by passing air contaminated with trichloroethylene (TCE) and perchloroethylene (PCE) through the reactor at an inlet temperature of $104^{\circ}$ to $122^{\circ} \mathrm{F}$ and an inlet humidity of $15 \%$ to $25 \%$ R.H. to simulate expected field conditions. ${ }^{(a)}$

Nine tests were performed to determine destruction efficiencies and byproduct formation at three different contaminant concentrations and three different flow rates. The three inlet contaminant conditions were

- PCE at $763 \pm 16 \mathrm{ppmv}$

- TCE at $920 \pm 29 \mathrm{ppmv}$

- Mixture of PCE at $810 \pm 37$ ppmv and TCE at $365 \pm 50$ ppmv.

The three inlet flow rates were (with reactor-residence times in parentheses)

- $0.5 \mathrm{cfm}(3.1-\mathrm{s}$ residence time)

- $1.0 \mathrm{cfm}(1.6-\mathrm{s}$ residence time)

- $2.0 \mathrm{cfm}$ (0.8-s residence time).

The inlet flowrates were measured and controlled using a Sierra mass-flow controller. Stream temperatures, pressures and humidities were measured at the inlet and outlet of the reactor using the same sensors described in Section 3.3. To create a humidified air stream, air was pulled by a slight vacuum through a water bubbler at room temperature. To add known quantities of each contaminant, compressed air was passed through gas-washing bottles containing pure liquid TCE and PCE and mixed with the humidified air stream. The simulated offgas was then passed through a stainless steel pipe wrapped with heat tape and containing an in-line heater to simulate field offgas temperatures at the reactor inlet.

For all laboratory tests, the HEC reactor was operated at a constant voltage of $30 \mathrm{kV}$ at $60 \mathrm{~Hz}$. Table 4.1 lists the amperage and power associated with each test.

(a) Field conditions were calculated by assuming that the off-gas stream, as removed from the soil, would be water-saturated at $60^{\circ} \mathrm{F}$, then compressed to 4 psig and heated to 100 to $120^{\circ} \mathrm{F}$, resulting in a final 15 to $20 \%$ R.H. 
Table 4.1. Energy Requirement per Pound of Contaminant Treated

\begin{tabular}{|c|c|c|c|c|c|c|}
\hline \multirow[b]{2}{*}{ Compound } & \multicolumn{2}{|c|}{3.1 second } & \multicolumn{2}{|c|}{1.6 second } & \multicolumn{2}{|c|}{0.80 second } \\
\hline & Current & Power & Current & Power & Current & Power \\
\hline PCE (763 ppm) & 33.5 & 1.00 & 31.5 & 0.94 & 30 & 0.90 \\
\hline TCE (920 ppm) & 36 & 1.08 & 31.5 & 0.94 & 30 & 0.90 \\
\hline $\begin{array}{l}\text { PCE (810 ppm) } \\
\text { TCE (365 ppm) }\end{array}$ & 30 & 0.90 & 30.5 & 0.91 & 30 & 0.90 \\
\hline
\end{tabular}

\subsection{Laboratory Destruction Efficiencies}

Destruction efficiencies for TCE and PCE were determined by measuring their concentrations at the inlet and outlet of the HEC reactor using an online HP 5890 Series I, 12-port autosampling gas chromatograph equipped with a Flame Ionization Detector (FID), an HP 3396 Series II integrator, and either a Megabore DB1 column at $40^{\circ} \mathrm{C}$ or a Megabore DB624 column at $100^{\circ} \mathrm{C}$. The sample injection size was $1 \mathrm{ml}$, the nitrogen carrier-gas flow was $30 \mathrm{ml} / \mathrm{min}$, the hydrogen flow was $30 \mathrm{ml} / \mathrm{min}$, and the air flow was 390 to $400 \mathrm{ml} / \mathrm{min}$. Using this system, samples of the reactor inlet and outlet were automatically obtained and analyzed every $3.5 \mathrm{~min}$ during reactor operation and control testing.

Table 4.2 lists the destruction efficiencies observed for all nine laboratory tests performed under simulated field conditions. Destruction efficiencies of $99 \%$ were typically observed for TCE as a single component; slightly lower when mixed with PCE. Destruction of PCE as a single component ranged from $58 \%$ to $85 \%$ depending on residence time (inlet flow rate). In the presence of TCE, PCE destruction ranged from $65 \%$ to only $69 \%$.

Table 4.2. Observed Destruction Efficiencies of TCE/PCE

\begin{tabular}{|c|c|c|c|}
\hline Reactor Inlet (ppmv) & 0.5 SCFM (\%) & 1.0 SCFM (\%) & 2.0 SCFM (\%) \\
\hline PCE @ $763 \pm 16$ & $85.4 \pm 0.6$ & $81.6 \pm 0.9$ & $57.5 \pm 2.0$ \\
\hline TCE @ $920 \pm 29$ & $98.9 \pm 0.2$ & $99.8 \pm 0.1$ & $99.4 \pm 0.6$ \\
\hline PCE @ $810 \pm 37$ & $69.4 \pm 2.0$ & $62.8 \pm 1.2$ & $64.6 \pm 2.0$ \\
\hline TCE @ $364 \pm 50$ & $99.7 \pm 0.1$ & $98.4 \pm 0.1$ & $98.6 \pm 0.2$ \\
\hline
\end{tabular}




\subsection{Laboratory Byproduct Formation}

Techniques used for analyzing byproducts both on- and off-line were developed with advice from WSRC staff based on the following list of suspected byproducts:

- carbon tetrachloride

- chloroform

- phosgene

- dichloroacetylchloride (DCAC)

- hexachloroethane

- pentachloroethane.

The targeted reactor byproducts were measured both on-line (using the same HP 5890 system) and off-line. The online procedure employed the same Megabore DB624 column but under nonisothermal conditions and with a nitrogen carrier-gas flow of $24 \mathrm{ml} / \mathrm{min}$. Also, before each byproduct analysis, the system was baked out for 15 to $20 \mathrm{~min}$ at $225^{\circ} \mathrm{C}$. The oven sequence was isothermal for $3.0 \mathrm{~min}$ at $35^{\circ} \mathrm{C}$, ramped at $3.0^{\circ} \mathrm{C}$ per min to $50^{\circ} \mathrm{C}$, and finally ramped at $25^{\circ} \mathrm{C}$ per min to $225^{\circ} \mathrm{C}$. At the end of each test, one gas sample was obtained from the reactor effluent and analyzed for byproducts.

The off-line procedure for byproduct analysis used a second HP 5890 GC connected to an HP 5971 MSD that was configured with a 1-ml injection loop and a 20-cm/s MSD linear velocity, with He as the carrier gas on a narrow-bore DB5/60-m column. Species separation was nonisothermal at $50^{\circ} \mathrm{C}$ for $4.9 \mathrm{~min}$ and then ramped at $30^{\circ} \mathrm{C}$ per min to a final temperature of $180^{\circ} \mathrm{C}$. During each test, at least three scan-mode samples were extracted by glass syringe from the reactor effluent at three different time periods corresponding to reactor start-up, pre-steady-state, and steady-state operation.

Table 4.3 lists the observed steady-state decomposition products for the tests performed with TCE at an inlet concentration of 920 ppmv. The predominant byproducts detected were DCAC and pentachloroethane. Perchloroethylene was also detected as a contaminated in the TCE used for testing its concentrations are not shown. Concentrations of DCAC in particular were observed to increase rapidly with decreasing reactor-residence time. For most of the tests, phosgene was detected in the reactor outlet but could not be quantified. Likewise, trace amounts of chloroform (below 1 ppmv) were detected in all the samples.

Table 4.4 lists the observed decomposition products for PCE at an inlet concentration of $763 \mathrm{ppmv}$. Concentrations of DCAC were markedly lower for PCE destruction than observed for TCE destruction. Pentachloroethane was also lower (below detection limits), whereas hexachloroethane was detected in small concentrations. 
Table 4.3. Byproduct Concentrations for Trichloroethylene (TCE)

\begin{tabular}{|c|c|c|c|}
\hline Compound & $\begin{array}{c}3.1 \mathrm{sec} \\
(\mathrm{ppm})\end{array}$ & $\begin{array}{l}1.6 \mathrm{sec} \\
(\mathrm{ppm})\end{array}$ & $\begin{array}{c}0.80 \mathrm{sec} \\
\text { (ppm) }\end{array}$ \\
\hline Perchloroethylene & $31.0 \pm 1.1$ & $20.9 \pm 0.8$ & $39.1 \pm 1.4$ \\
\hline Trichloroethylene & $10.2 \pm 0.6$ & $1.98 \pm 0.1$ & $4.8 \pm 0.3$ \\
\hline Carbon Tetrachloride & Approx 2 & Approx 4 & Approx 3 \\
\hline Phosgene & $\mathbf{N} / \mathbf{Q}$ & N/Q & $\mathbf{N} / \mathbf{Q}$ \\
\hline Dichloroacetylchloride & $1.0 \pm 0.7$ & $8.42 \pm 5.8$ & $24.8 \pm 17.2$ \\
\hline Hexachloroethane & Trace & Trace & $\mathrm{N} / \mathrm{D}$ \\
\hline Pentachloroethane & $7.6 \pm 0.3$ & $6.1 \pm 0.3$ & Trace \\
\hline \multicolumn{4}{|l|}{ N/D Not detected } \\
\hline \\
\hline $\begin{array}{ll}\text { N/M } & \text { Not measured } \\
\text { N/O } & \text { Present but not auantified }\end{array}$ & & & \\
\hline
\end{tabular}

Table 4.4. Byproduct Concentrations for Perchoroethylene (PCE)

\begin{tabular}{l}
\multicolumn{1}{c}{ Compound } \\
\hline Perchloroethylene \\
Carbon Tetrachloride \\
Phosgene \\
Dichloroacetylchloride \\
Hexachloroethane \\
Pentachloroethane
\end{tabular}

\begin{tabular}{c}
$3.1 \mathrm{sec}(\mathrm{ppm})$ \\
\hline $106.7 \pm 3.9$ \\
Approx 4 \\
N/Q \\
N/Q \\
N/Q \\
N/M
\end{tabular}

\begin{tabular}{c}
$1.6 \mathrm{sec}(\mathrm{ppm})$ \\
\hline $137.0 \pm 5.0$ \\
Approx 4 \\
N/D \\
Trace \\
$4.3 \pm 0.4$ \\
N/D
\end{tabular}

$0.80 \mathrm{sec}(\mathrm{ppm})$

$331.2 \pm 12.2$

Approx 2

N/Q

$1.0 \pm 0.4$

$3.5 \pm 0.3$

N/D

N/D Not detected

N/M Not measured

N/Q Present but not quantified

Table 4.5 lists the observed decomposition products for PCE at an inlet concentration of 810 ppmv combined with TCE at 364 ppmv. Effluent analyses for these tests indicated a curious decrease in hexachloroethane as the flowrate increased. Other byproducts like DCAC remained essentially the same as in the single-component tests.

As indicated in Tables $4.3,4.4$, and 4.5 , the primary organic byproducts were dichloroacetyl chloride (DCAC), hexachloroethane, and pentachloroethane. The maximum percent of organic carbon byproduct based on total inlet organic carbon yielded less than $2.7 \%$ DCAC, $2.8 \%$ hexachloroethane, and $0.85 \%$ pentachloroethane at $0.80 \mathrm{sec}$ residence time. 
Table 4.5. Byproduct Concentrations for Mixture of PCE and TCE

\begin{tabular}{l}
\multicolumn{1}{c}{ Compound } \\
\hline Perchloroethylene \\
Trichloroethylene \\
Carbon Tetrachloride \\
Phosgene \\
Dichloroacetylchloride \\
Hexachloroethane \\
Pentachloroethane
\end{tabular}

\begin{tabular}{c}
3.1 sec (ppm) \\
\hline $275.6 \pm 10.1$ \\
$1.5 \pm 0.1$ \\
Approx 5 \\
N/Q \\
$4.5 \pm 3.1$ \\
$34.0 \pm 3.4$ \\
$10.0 \pm 0.4$
\end{tabular}

$\begin{array}{ccc}1.6 \mathrm{sec}(\mathrm{ppm}) & & 0.80 \mathrm{sec}(\mathrm{ppm}) \\ 301.4 \pm 11.1 & & 265.2 \pm 9.7 \\ 5.9 \pm 0.4 & & 3.8 \pm 0.2 \\ \text { Approx } 3 & & \text { Approx } 2 \\ \text { N/Q } & & \text { N/Q } \\ 4.5 \pm 3.1 & & 8.0 \pm 5.5 \\ 9.0 \pm 0.9 & & 3.5 \pm 0.3 \\ 2.8 \pm 0.1 & & \text { N/D }\end{array}$





\subsection{Field Tests}

The field tests were conducted in two phases. The first phase consisted of preoperational testing using pure TCE in air. These tests were conducted to ensure proper system operation before actual demonstration testing and to compare destruction efficiencies and byproduct levels measured using the on-line GC/FID system (described in Section 4.0) with those determined by independent off-line analyses performed by WSRC. The effect of inlet humidity on destruction efficiency, power requirements, and byproduct formation was also investigated during the preoperational tests to enable the inlet humidity to be optimized for the second phase of the field demonstration. ${ }^{\text {(a) }}$

Eight preoperational tests were performed under the conditions listed in Table 5.1. Preoperational Tests 1 through 4 investigated the effect of humidity from $45 \%$ to $90 \%$ R.H. in $15 \%$ increments; Tests 1 and 5 compared the performance of two of the reactor banks ( $A$ and $C$ ) with all other conditions constant; and Tests 5 through 8 investigated the effect of flowrate from 7.0 to $28.0 \mathrm{cfm}$ using a single reactor bank (Bank C). All of the preoperational tests were conducted at power-supply voltages of $30 \mathrm{kV}$.

The second phase of tests comprised the actual field demonstration to evaluate the performance of the HEC process in treating the actual TCE/PCE-contaminated soil-offgas stream. Table 5.2 lists the flow rates and bank configurations that were tested. All of the offgas treatment tests were conducted at power-supply voltages of $30 \mathrm{kV}$. Based on humidity data from the preoperational tests, all of the soiloffgas tests were conducted without adjusting the inlet humidity, which generally remained at $40 \%$ to $48 \%$ R.H.

Table 5.1. Preoperational Tests

\begin{tabular}{|c|c|c|c|c|c|}
\hline $\begin{array}{c}\text { Test } \\
\text { Number }\end{array}$ & $\begin{array}{c}\text { Inlet } \\
\text { Humidity }\end{array}$ & Bank & $\begin{array}{l}\text { Flow/Reactor } \\
\text { (cfm/reactor) }\end{array}$ & $\begin{array}{c}\text { Total Flow } \\
\text { (cfm) }\end{array}$ & $\begin{array}{l}\text { Residence } \\
\text { Time (sec) }\end{array}$ \\
\hline 1 & 45 & $\mathbf{A}$ & 1.0 & 7.0 & 1.6 \\
\hline 2 & 60 & B & 1.0 & 7.0 & 1.6 \\
\hline 3 & 75 & A & 1.0 & 7.0 & 1.6 \\
\hline 4 & 90 & B & 1.0 & 7.0 & 1.6 \\
\hline 5 & 45 & C & 0.5 & 3.5 & 3.1 \\
\hline 6 & 45 & C & 1.0 & 7.0 & 1.6 \\
\hline 7 & 45 & C & 2.0 & 14.0 & 0.8 \\
\hline 8 & 45 & C & 4.0 & 28.0 & 0.4 \\
\hline
\end{tabular}

(a) The humidity investigation was conducted in the field because, with an automated humidification system, the field process was capable of producing and controlling a wider range of inlet humidities than possible in the laboratory, and because the field process included real-time acquisition of power data, which was not available in the laboratory. 
Table 5.2. Offgas Treatment Tests

\begin{tabular}{|c|c|c|c|c|}
\hline $\begin{array}{c}\text { Demo Test } \\
\text { Number }\end{array}$ & $\begin{array}{c}\text { Banks } \\
\text { Operated }\end{array}$ & $\begin{array}{l}\text { Flow } \\
\text { (cfm) }\end{array}$ & $\begin{array}{l}\text { Flow/Reactor } \\
\text { (cfm/reactor) }\end{array}$ & $\begin{array}{l}\text { Residence } \\
\text { Time (sec) } \\
\end{array}$ \\
\hline 1 & A & 7.0 & 1.0 & 1.6 \\
\hline 2. & B & 7.0 & 1.0 & 1.6 \\
\hline 3 & C & 7.0 & 1.0 & 1.6 \\
\hline 4 & $\mathrm{ABC}$ & 10.5 & 0.5 & 3.1 \\
\hline 5 & $\mathrm{ABC}$ & 21.0 & 1.0 & 1.6 \\
\hline 6 & $\mathrm{AC}$ & 1.4 & 0.1 & 15.7 \\
\hline 7 & $\mathrm{ABC}$ & 42.0 & 2.0 & 0.8 \\
\hline
\end{tabular}

Before operating the system, absolute-pressure sensors located in the inlet and outlet system piping were used to verify a leak-proof system by static-pressure testing at $\sim 5 \mathrm{psig}$ (five times the average operating pressure of $\sim 1$ psig.)

\subsection{Demonstration Site History and Field Conditions}

Testing at the Savannah River Nonarid Integrated Demonstration site was performed on soil offgas removed from well number ZVE-4 next to A-014 outfall in the 3/700 area. Forty years of diluted, untreated waste from the Metal Fabrication Facility had left the clay/silt soil contaminated with trichloroethylene (TCE), perchloroethylene (PCE), and trichloroethane (TCA). At the time of the demonstation test, contaminant concentrations in the soil had not been completely characterized.

Westinghouse Savannah River Company (WSRC) installed an In Situ Air Stripping (ISAS) system consisting of a soil well (ZVE-4) that extended $115 \mathrm{ft}$ into the ground with a screened length of $60 \mathrm{ft}$. A blower connected to the soil vent pulled between 10-12" $\mathrm{Hg}$ vacuum on the well and discharged its effluent at a controllable pressure and temperature between $0.25-6$ psig and $90-105^{\circ} \mathrm{F}$, respectively. A cyclotron/liquid knock out drum and a particulate filter were located upstream of the blower to remove any entrained liquids and particulates $(>5 \mu \mathrm{m})$. Figure 5.1 is a schematic outline of WSRC's ISAS process.

The composition of the soil offgas stream varied seasonaly and with atmospheric conditions. The compositions averaged 10,000 ppmv PCE, 2,000 ppmv TCE, and $200 \mathrm{ppmv}$ TCA. The soil offgas was diluted with ambient air prior to enter the HEC system to approximately $686 \mathrm{ppmv}$ PCE and 101.8 ppmv TCE. TCA concentrations were not measured since standards were not available, however, trace concentrations $(<10 \mathrm{ppmv})$ were expected and were assumed to have negligible effects on the HEC experiments.

\subsection{Analytical Techniques Used for Field Testing}

Analyses of the inlet and effluent stream concentrations were performed both by PNL staff using the on-line GC/FID system described in Section 4.1 and by WSRC for independent confirmation of 


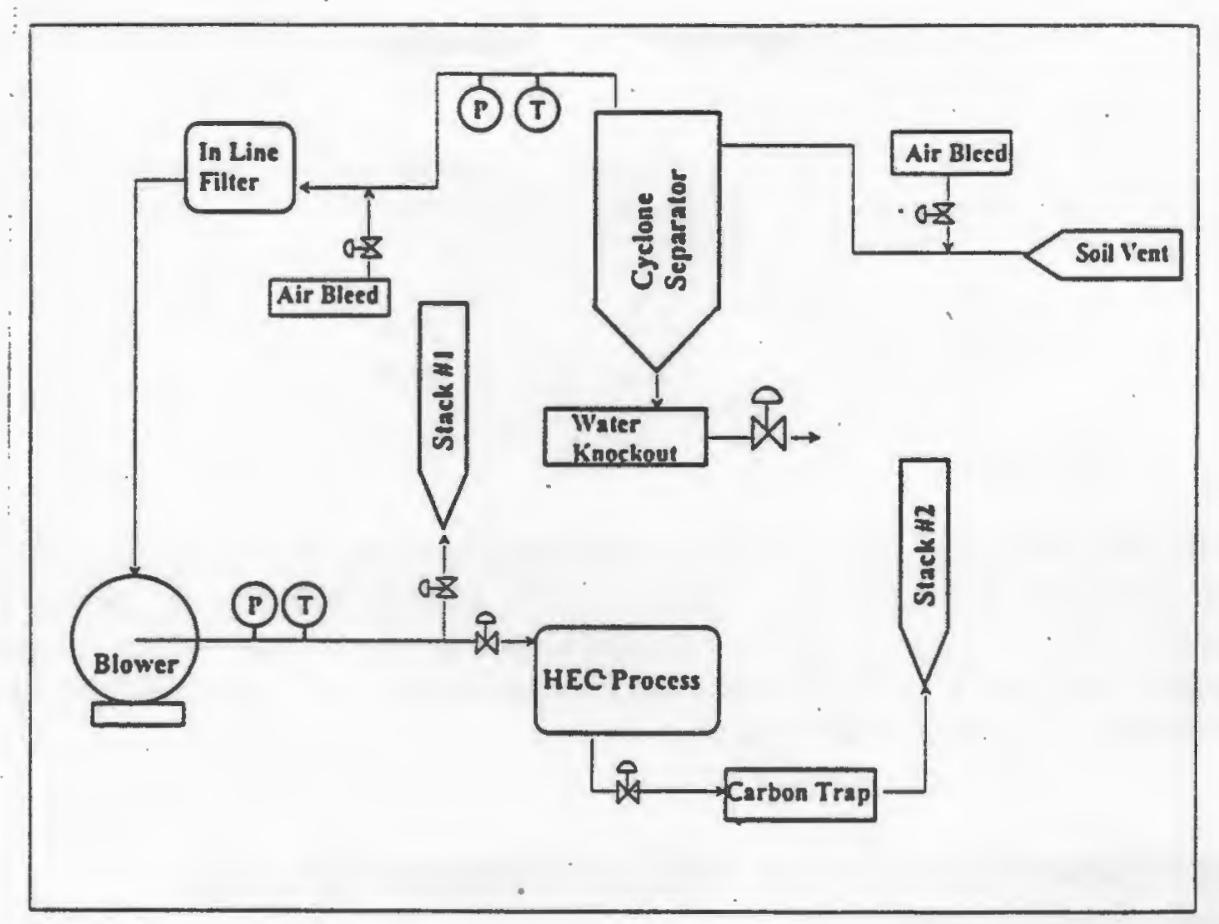

Figure 5.1. Schematic Design of Savannah River's ISAS System

system performance. In the event of discrepancies between the on-line and off-line techniques, the offline analyses performed by WSRC were considered the ultimate determination of destruction efficiency and byproduct levels because the same off-line analyses were used to measure the performance of all other technologies participating in the VOC-Nonarid ID. To conduct the off-line analyses, inlet and outlet grab samples were obtained by WSRC for determination of destruction efficiency using a gas chromatograph equipped with an electron-capture detector (ECD). The calibration standards used by WSRC were gravimetrically mixed and were thus not certified or analyzed for exact concentrations. As a result, destruction efficiencies greater than $99 \%$ were not determinable. However, an effective standard-concentration error range was determined using calibration data compiled by WSRC staff over a two-week testing period. Table 5.3 shows the variation of TCE and PCE over four days on the FID and ECD detectors. These variations reflect standard GC variations, but do not account for any dynamics inside the gas sampling bags. Additional grab samples were obtained and submitted to WSRC for off-line byproduct analysis using a purge-and-trap GC/MS, which detected for derivatized phosgene, DCAC, and trichloroacetylchloride (TCAC). Because derivatization and purge efficiencies were not accurately determined, analyses for these compounds were of indication-only quality.

To minimize errors due to sample dynamics, the grab samples were analyzed within two hours of being collected. All sampling was done using Tedlar bags. For all tests, a single sample wás collected within 10-min of reactor startup, and a second sample was collected following reactor stabilization (as determined by stable on-line measurements of destruction efficiency over a 30-min or longer operating period.) The Tedlar bags were inserted into valved connections in the effluent stream at a location outside the HEC trailer, upstream of an activated-carbon scrubber. The sample bags were filled once, purged, then filled a second time, sealed, and submitted to off-line analysis. The force 
Table 5.3. Variation in TCE/PCE Detection Between 5/9 and 5/13/93

\begin{tabular}{|c|c|c|c|}
\hline \multirow[b]{2}{*}{ Contaminant } & \multirow{2}{*}{$\frac{10 \mathrm{ppm}}{\operatorname{ECD}(\%)}$} & \multicolumn{2}{|c|}{$100 \mathrm{ppm}$} \\
\hline & & $\operatorname{ECD}(\%)$ & FID $(\%)$ \\
\hline TCE & 5.3 & 6.1 & 9.2 \\
\hline PCE & 12.5 & 5.3 & 6.5 \\
\hline
\end{tabular}

required to fill the sample bags was provided by backpressure in the effluent piping, which was dependent on the overall stream flowrate. Because of this, samples collected during Test 6 , involving an extremely low offgas flowrate $(1.4 \mathrm{cfm})$, required $15 \mathrm{~min}$ to fill one sample bag. To save time, the sample bags were not purged during this test, and only two samples were obtained; one during reactor startup and one following reactor stabilization.

\subsection{Effect of Inlet Humidity on HEC Performance During Preoperational Tests}

Table 5.4 summarizes the effect of inlet humidity on the destruction of pure TCE in air at a residence time of $1.6 \mathrm{~s}$ and a TCE concentration of $465 \pm 24 \mathrm{ppmv}$. Destruction efficiencies fell from $>99 \%$ at moderate $(45 \%)$ humidity to $97.3 \%$ at high $(90 \%)$ humidity. However, any trend is unclear because destruction did not vary monotonically with inlet humidity. If anything, the test results suggest that the use of two different reactor banks (A and B) may have had a greater effect on destruction efficiency than differences in inlet humidity. The tests conducted using Bank A at $45 \%$ and $75 \%$ R.H. resulted in higher destruction efficiencies than measured using Bank B at $60 \%$ and $95 \%$ R.H.

Table 5.5 shows that the relative concentration of byproducts in the effluent increased with humidity. Because thorough byproduct calibrations could not be made using the gravimetric calibration standards available in the field, relative concentrations were calculated from the on-line chromatographs by normalizing (assigning a value of one to) the concentrations of each byproduct peak obtained

Table 5.4. Effect of Inlet Humidity on Destruction of Pure TCE

\begin{tabular}{|c|c|c|c|c|}
\hline $\begin{array}{c}\text { Shakedown } \\
\text { Test }\end{array}$ & $\begin{array}{c}\text { Reactor } \\
\text { Bank }\end{array}$ & $\begin{array}{c}\text { Inlet Humidity } \\
\text { (\% Relative } \\
\text { Humidity) }\end{array}$ & $\begin{array}{l}\text { Inlet TCE } \\
\text { (ppmv) }\end{array}$ & $\begin{array}{c}\text { TCE Destruction } \\
\text { Efficiency (\%) }\end{array}$ \\
\hline 1 & A & $47.7 \pm 1.5$ & $446 \pm 28$ & $\geq 99$ \\
\hline 2 & B & $57.0 \pm 9.0$ & $454 \pm 20$ & $98.6 \pm 0.5$ \\
\hline 3 & A & $76.2 \pm 7.9$ & $462 \pm 24$ & $\geq 99$ \\
\hline 4 & B & $91.8 \pm 9.6$ & $500 \pm 7.7$ & $97.3 \pm 0.7$ \\
\hline
\end{tabular}


Table 5.5. Effect of Inlet Humidity on Byproduct Formation

\begin{tabular}{|c|c|c|c|c|}
\hline Compound & 45\% R.H. & $60 \%$ R.H. & 75\% R.H. & 90\% R.H. \\
\hline Carbon Tetrachloride & 1.0 & 0.8 & $N / D$ & 0.8 \\
\hline DCAC & 1.0 & 2.0 & 2.0 & 4.4 \\
\hline Pentachloroethane & 1.0 & 1.5 & 1.7 & 3.2 \\
\hline
\end{tabular}

Note: Concentrations are normalized at $45 \%$ R.H.

at $45 \%$ R.H. From $45 \%$ to $90 \%$ R.H., outlet concentrations of DCAC increased by $425 \%$ while pentachloroethane increased by $323 \%$. As shown, the largest increase in byproduct concentrations seemed to occur at higher humidities (between $75 \%$ and $90 \%$ ). However, the byproduct distributions may also have been affected by differences in performance between Banks A and B.

Figure 5.2 illustrates the effect on reactor power of increasing humidity at the reactor inlet. As shown, power requirements were only slightly affected by humidity, with an $8.3 \%$ increase in power associated with a $45 \%$ increase in humidity (from $45 \%$ to $90 \%$ R.H.)

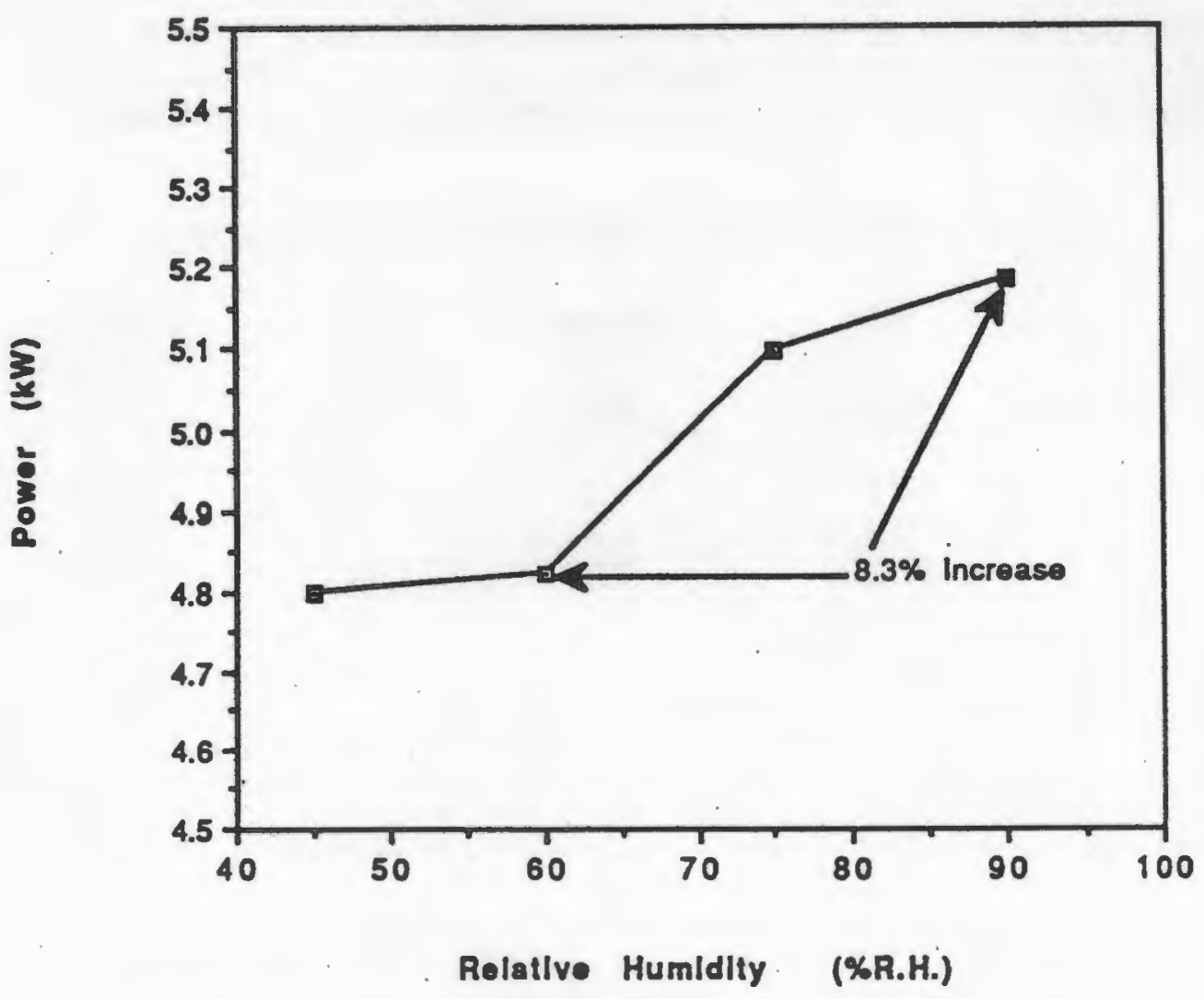

Figure 5.2. Effect of Inlet Humidity on High-Energy Corona Power 
Because increased humidity caused increased byproduct levels, required marginally more power, and potentially decreased destruction efficiencies, all subsequent tests with pure TCE were run at $45 \%$ R.H. Likewise, for subsequent soil offgas treatment tests, the humidity of the soil offgas entering the HEC process was not altered (increased) because an optimum in R.H. was either not detected, or appeared to occur at an R.H. of $45 \%$ or lower. Based on laboratory experience, an optimum in stream humidity probably exists between $15 \%$ and $45 \%$ R.H. because, as humidity is increased within this range, the HEC plasma visibly shifts from violently sparking to homogeneously glowing, with an apparently corresponding increase in destruction efficiency.

\subsection{Effect of Reactor Residence Time on HEC Performance During Preoperational Tests}

Table 5.6 summarizes the effect of reactor residence time on the destruction of pure TCE in air at $45 \%$ R.H. using reactor-Bank C. Destruction efficiencies for TCE ranged from $96.1 \%$ to $>99 \%$ with increasing reactor-residence times. The listed destruction efficiencies were measured after the reactor performance had reached steady state, based on 3 to 4 reproducible destruction values.

Table 5.7 lists the amperage, power, and an energy cost per pound of TCE treated associated with each TCE destruction test in Table 5.1. This estimate is based on the measured destruction efficiency (from Table 5.6) and reflects the operating cost of the HEC reactor. Operating costs obviously decrease as more contaminant is fed to the reactor. An electrical unit cost of $\$ 0.05$ per $\mathrm{kW}$-hr was used for these calculations, corresponding to the average, projected commercial cost of electricity in the Pacific Northwest over a 30 -yr period, as quoted by Westinghouse Hanford Company staff.

Table 5.6. Effect of Residence Time on Destruction of Pure TCE

\begin{tabular}{|c|c|c|c|c|}
\hline $\begin{array}{l}\text { Preoperational } \\
\text { Test Number }\end{array}$ & $\begin{array}{c}\text { Inlet } \\
\text { TCE } \\
\text { (ppmv) }\end{array}$ & $\begin{array}{c}\text { Residence } \\
\text { Time } \\
\text { (sec) }\end{array}$ & $\begin{array}{l}\text { Total } \\
\text { Flow } \\
\text { (cfm) }\end{array}$ & $\begin{array}{c}\text { Destruction } \\
\text { Efficiency } \\
(\%)\end{array}$ \\
\hline 5 & $701 \pm 19$ & 3.1 & 3.5 & $\geq 99$ \\
\hline 6 & $341 \pm 15$ & 1.6 & 7.0 & $\geq 99$ \\
\hline 7 & $335 \pm 22$ & 0.8 & 14.0 & 97.4 \\
\hline 8 & $364 \pm 32$ & 0.4 & 28.0 & 96.1 \\
\hline
\end{tabular}

Note: Tests 5 through 8 were performed on reactor Bank C. 
Table 5.7. Electrical Requirements and Costs for Destruction of Pure Trichloroethylene Treatment

\begin{tabular}{|c|c|c|c|}
\hline \multirow[b]{2}{*}{ Preoperational } & \multicolumn{3}{|c|}{ Power Requirements } \\
\hline & Current & Power ${ }^{(a)}$ & Cost (\$/lb TCE) \\
\hline 5 & 160 & 5.0 & 5.01 \\
\hline 6 & 170 & 5.1 & 5.25 \\
\hline 7 & 179 & 5.4 & 2.82 \\
\hline 8 & 175 & 5.3 & 1.07 \\
\hline
\end{tabular}

(a) Reported power does not include phase angle relationship between current and voltage. Reported values are based on rms voltage and current. Actual power would be lower.

\subsection{Destruction Efficiencies for Trichloroethylene Measured During Offgas Treatment Tests}

Figure 5.3 illustrates steady-state destruction efficiencies for TCE in soil-offgas treated by the HEC process. TCE destruction measured using the on-line GC/FID system was $>99 \%$ for all except the lowest residence time tested $(0.8 \mathrm{~s}$, corresponding to a per-reactor flow of $2.0 \mathrm{cfm}$, or a total

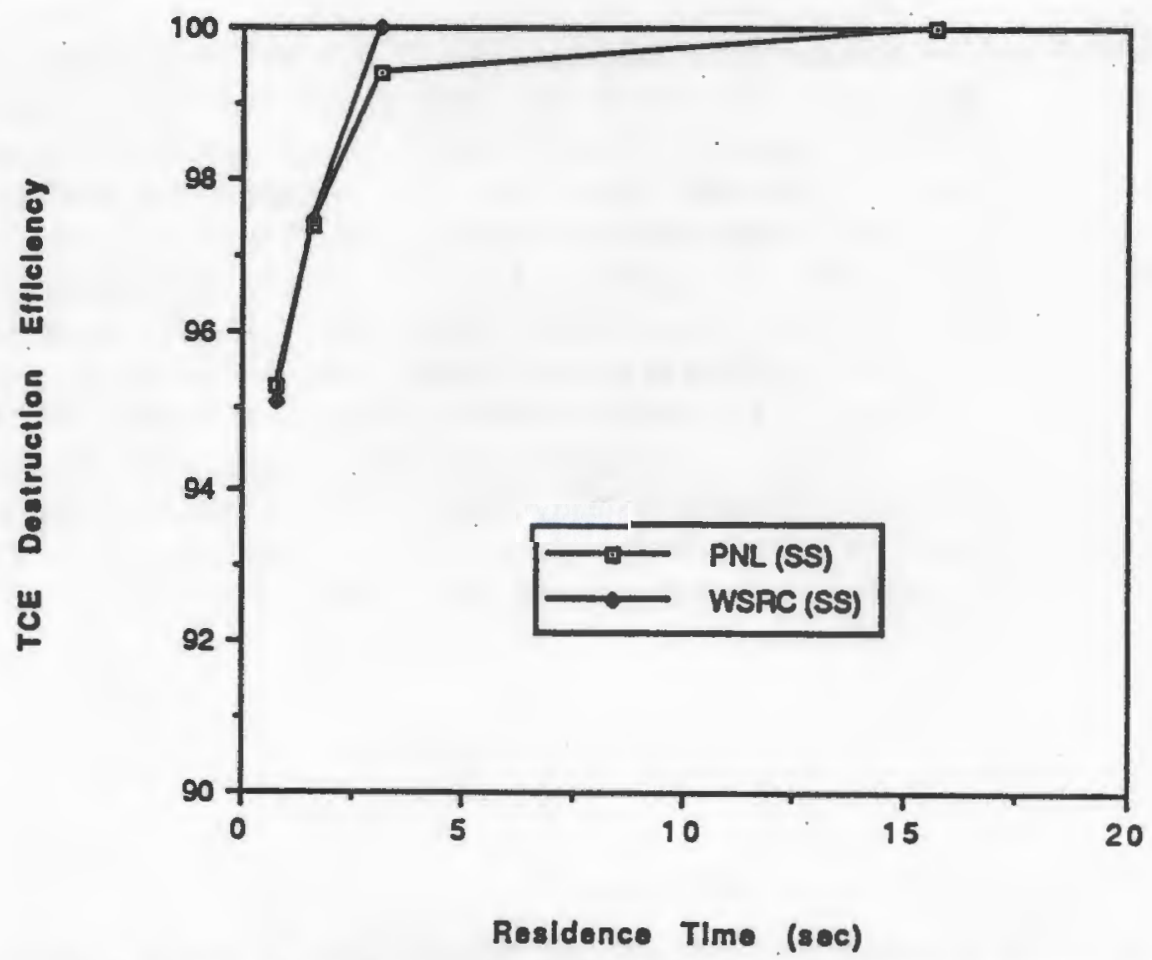

Figure 5.3. Steady State Destruction Efficiencies for Trichloroethylene in Soil Offgas 
process treatment rate of $42.0 \mathrm{cfm}$ ) where TCE destruction efficiency fell to $95 \%$. Destruction efficiencies measured off-line by WSRC and on-line by PNL agreed within 2\%. All samples for Figure 5.3 were collected at the end of the test following reactor stabilization as determined by on line GC/FID measurements. During Test 5 (corresponding to a 1.6-s residence time), two sparkovers occurred in bank B, forcing it to be set at a lower operating voltage of $27 \mathrm{kV}$, resulting in a lower TCE destruction efficiency of $93.5 \%$. Based on a material balance and assuming flows through each bank were uniformly equal, the overall decrease in TCE destruction can be accounted for by the voltage reduction in Bank B.

An effluent-sampling error occurred during Test 6 conducted at a flowrate of $0.1 \mathrm{cfm} /$ reactor. At this low flowrate, the backpressure on the effluent side of the process was extremely low, requiring 10 to $15 \mathrm{~min}$ to fill a Tedlar sampling bag. Because of the time required to fill the bag, only one sample was collected. Since all other sampling operations associated with tests at higher flowrates (and thus higher backpressures) were completed well within $5 \mathrm{~min}$, a PNL staff member in the HEC trailer assumed that the effluent sample had been collected (outside the trailer) and inadvertently switched process conditions during the actual 15-min sampling period. The responsible WSRC test engineer was informed immediately of this error. Due to time constraints, it was not possible to repeat the experiment. The more conservative on-line measurements were used to determine destruction efficiency for this test.

\subsection{Destruction Efficiencies for Perchloroethylene Measured During Offgas Treatment Tests}

Figure 5.4 presents steady-state destruction efficiencies for PCE in soil offgas treated by the HEC process. As can be seen, differences between the on-line (PNL) and off-line (WSRC) analyses were pronounced. (a) Based on the off-line analyses, PCE destruction increased monotonically between $73.3 \%$ and $94 \%$ with increasing residence time from 0.8 to $3.1 \mathrm{~s}$. (As mentioned in Section 5.5, a sampling error prevented collection of a representative sample for Test 6 at a 15.7-s residence time.) However, the more conservative on-line results shown in Figure 5.4 clearly demonstrate a level of $\geq 99 \%$ destruction of PCE at this flowrate. As mentioned before, during Test 5 (corresponding to a 1.6-s residence time), two sparkovers occurred in Bank B, forcing Bank B to be set at a lower operating voltage. Bank B registered a $2.5 \%$ decrease in overall destruction. Destruction efficiencies for PCE were also measured at $\sim 10$ min into startup of the treatment system, with results as shown in Figure 5.5. Compared to process performance at steady state, levels of destruction at start-up were $20 \%$ higher at a 1.6-s residence time (as measured by both WSRC and PNL) and 13\% higher at a 3.1-s residence time (as measured by PNL). Laboratory studies, as well as field tests, have consistently indicated greater PCE destruction at startup as compared to steady state.

(a) As discussed in Section 5.1, in the event of discrepancies between the on-line and off-line techniques, the off-line analyses performed by WSRC were considered the ultimate determination of destruction efficiency and byproduct levels because the same off-line analyses were used to measure the performance of other technologies participating in the VOC-Nonarid ID. 


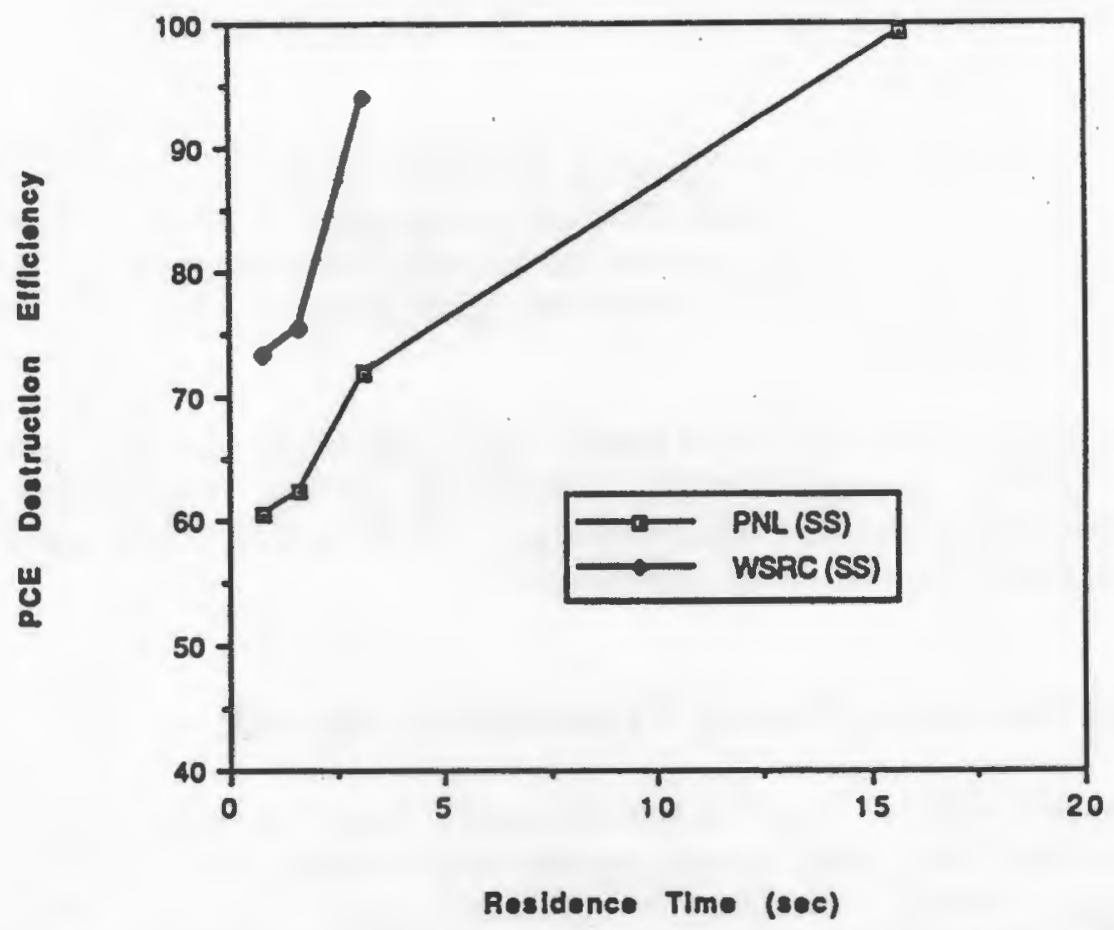

Figure 5.4. Steady State Destruction Efficiencies for Perchloroethylene in Soil Offgas

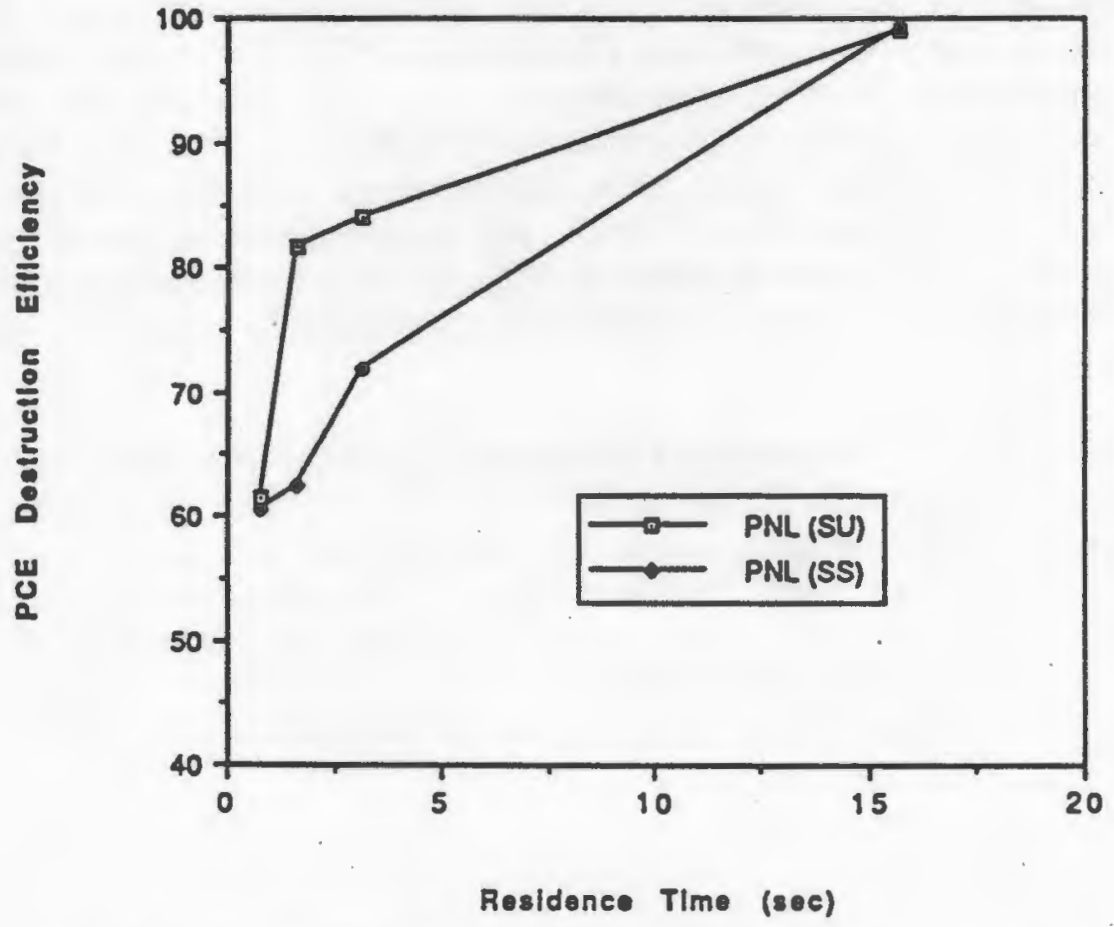

Figure 5.5. Startup Destruction Efficiencies for Perchloroethylene in Soil Offgas 


\subsection{Comparison Between On-Line and Off-Line Determination of Destruction Efficiency}

As indicated by the data presented in Figure 5.4, destruction efficiencies for PCE measured on- and off-line differed by as much as $18 \%$. Simple diffusion of contaminants from the sample bags could have also caused the observed differences between the on- and off-line measurements. However, this must be ruled out based on data from WSRC on the negligible effect of a 2-h period between sample collection and sample analysis.

PCE deviations may have occurred in the sample bags during the 2-h period between sampling and analysis since the HEC effluent is known to contain strong oxidants. Because levels of TCE destruction exceeded $95 \%$, further destruction of residual TCE in the sample bags may have been undetectable within the limits of analytical uncertainty.

\subsection{Byproduct Formation During Treatment of Soil Offgas}

Figure 5.6 presents byproduct concentrations measured at steady state as a function of reactor residence time. As might be expected, the total amount of byproducts varied inversely with reactor residence time. At all residence times, less than $3 \mathrm{ppmv}$ total of trichloronitromethane, trichloroacetylchloride (or trichloroacetylaldehyde), pentachloroethane, and hexachloroethane were detected in the process effluent.

Chloroform and carbon tetrachloride concentrations varied between 5-10 ppmv. Dichloroacetylchloride was suspected based on off-line GC/ECD measurements but was not detected by the GC/MS analysis. Phosgene was measured indirectly as a derivatized compound at concentrations roughly quantified in the 4-10 ppmv range. Trichloronitromethane was suspected in the effluent, based on MS scans in the 30-AMU range (corresponding to the presence of $\mathrm{N}-\mathrm{O}$ groups), but calibration standards were unavailable for positive verification. Spectra fitting chloromethane, methylene chloride, and 1,1-dichloroethane were also detected by off-line GC/MS, suggesting the presence of trichloroethane (TCA) in the offgas stream. However, standards for TCA, chloromethane, methylene chloride and 1,1-dichloroethane were also unavailable, so neither their concentrations nor positive identification could be established.

The percent of organic-carbon byproduct formation was calculated from WSRC GC/MS results for each of the four residence time tests. These values were based on compounds produced by the HEC process: phosgene, trichloroacetylchloride, hexachloroethane, trichloronitromethane, chloroform, carbon tetrachloride, chloroethane, and 1,1-dichloroethane. Inlet organic carbon from PCE, TCE, and TCA that was not destroyed by the process were not included. As expected, the highest organic carbon byproduct percentages were observed at a 0.8 -s residence time while the lowest percentages were observed at a 15.7-s residence time. Table 5.8 summarizes the field results for tests 4-7. 


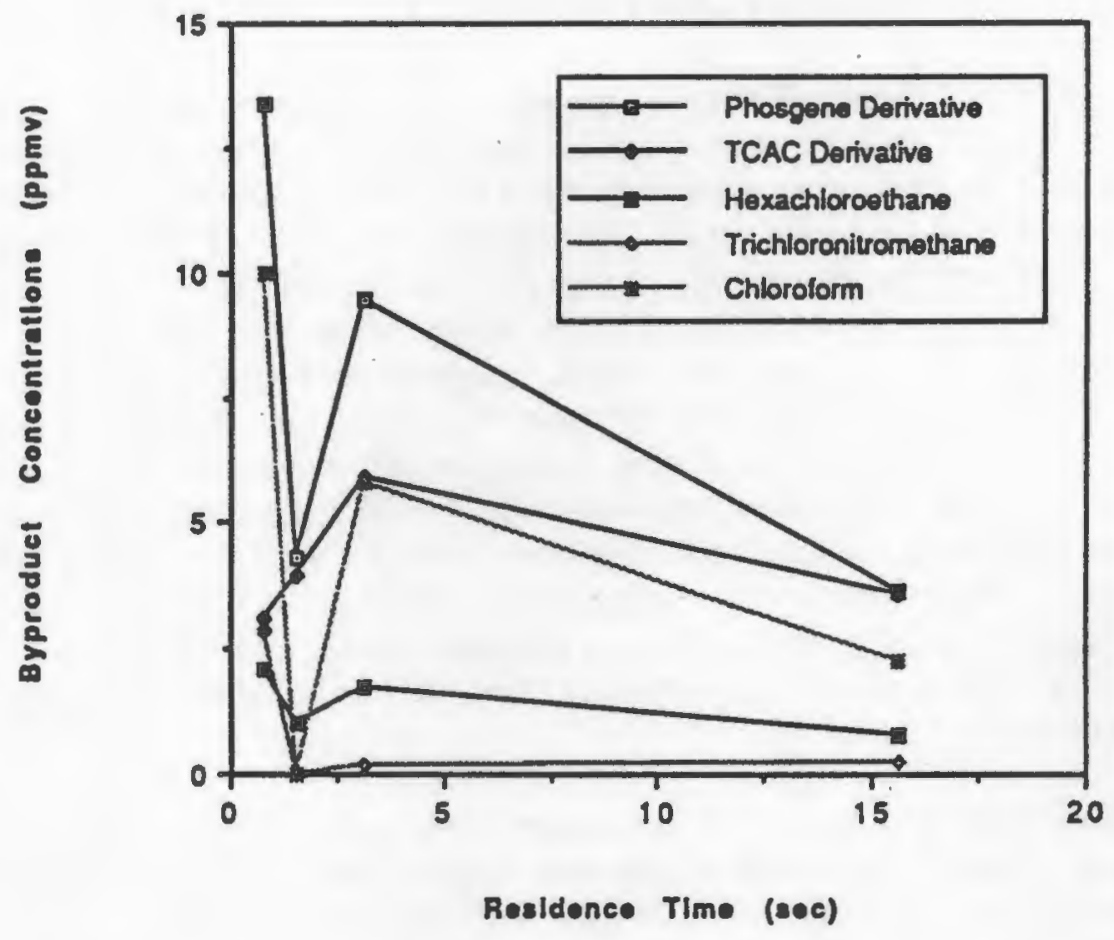

Figure 5.6. Effect of Residence Time on Byproduct Distributions from Offgas Treatment

Table 5.8. Percentage of Byproduct Organic Carbon

\begin{tabular}{|c|c|c|c|c|c|c|c|c|c|}
\hline $\begin{array}{l}\text { Residence } \\
\text { Time (s) }\end{array}$ & $\begin{array}{c}\text { Phosgene } \\
(\%)\end{array}$ & $\begin{array}{c}\operatorname{TCAC}^{(a)} \\
(\%)\end{array}$ & $\begin{array}{c}\mathrm{HCE}^{(b)} \\
(\%)\end{array}$ & $\begin{array}{c}\operatorname{TCNM}^{(c)} \\
(\%)\end{array}$ & $\begin{array}{l}\mathrm{CF}^{(d)} \\
(\%)\end{array}$ & $\begin{array}{l}C T^{(0)} \\
(\%)\end{array}$ & $\begin{array}{c}\mathrm{CM}^{(\mathrm{f})} \\
(\%)\end{array}$ & $\begin{array}{c}1,1 \mathrm{DCE}{ }^{(\mathrm{g})} \\
(\%)\end{array}$ & $\begin{array}{l}\text { Total } \\
(\%)\end{array}$ \\
\hline 0.8 & 0.9 & 0.4 & 0.3 & 0.2 & 0.7 & 0.2 & 0.6 & 0.9 & 4.2 \\
\hline 1.6 & 0.3 & 0.5 & 0.1 & 0.0 & 0.0 & 0.3 & 0.6 & 0.6 & 2.4 \\
\hline 3.1 & 0.6 & 0.7 & 0.2 & 0.01 & 0.4 & 0.3 & 0.5 & 0.6 & 3.3 \\
\hline 15.7 & 0.2 & 0.4 & 0.1 & 0.01 & 0.1 & 0.3 & 0.1 & 0.2 & 1.5 \\
\hline
\end{tabular}
(a) Trichloroacetyl Chloride/Aldehyde.
(b) Hexachloroethane.
(c) Trichloronitromethane (Suspected).
(d) Chloroform.
(e) Carbon Tetrachloride.
(f) Chloromethane.
(g) 1,1-Dichloroethane. 


\subsection{Effect of Reactor Bank on Destruction of PCE and TCE in Soil Offgas}

Offgas treatment Tests 1 through 3 were performed to discriminate between the destruction efficiencies achieved by each of the three reactor banks. Each test was run on a single bank for at least 45 min to achieve multiple steady-state measurements of PCE/TCE destruction. Between tests, PCE/ TCE concentrations at the process inlet varied only slightly. The results presented in Table 5.9 indicate that the three reactor banks exhibited similar performance. Figure 5.7 also presents destruction efficiencies for PCE for each of the reactor banks, as well as the combined process effluent stream as a function of residence time for Tests 4 through 7. Sampling ports for the on-line GC/FID were located at each of the outlets for the three reactor banks, ${ }^{(a)}$ enabling the effluent from each bank to be analyzed separately. These data show that higher destruction efficiencies were attained in Bank $\mathrm{C}$ as compared to Banks A and B. Throughout tests 4 through 7, Bank C appeared to operated smoothly while Banks A and B exhibited incidental sparking disruptions at a normal operating voltage of $30 \mathrm{kV}$. Some of the disruptions caused sparkover, creating current surges that automatically disabled the reactor bank's power supply by tripping an over-current protection relay. This allowed soil offgas to pass untreated through the disabled reactor bank until the bank could be brought back on line, which generally required 30 to $60 \mathrm{~s}$.

Unusual sparking about 8 to 12 in. from the bottom of the reactor was observed when treating the ISAS off gas stream. Banks A and B sparked the most violently and exhibited arcing from the center electrode to the reactor wall. Under these conditions, both banks were adjusted to slightly lower voltages (below $29 \mathrm{kV}$ ). Minerals/aerosols entrained in the off gas vent may possibly have caused this unusual sparking. As mentioned in Sections 5.5 and 5.6, two sparkovers occurred in Bank B during Test 5 (corresponding to a 1.6-s residence time), forcing Bank B to be set to a lower operating voltage of $27 \mathrm{kV}$, which resulted in a lower destruction efficiency of $93.5 \%$. Consequently, overall TCE destruction during Test 5 was $97 \%$ even though Banks A and C operated at $99 \%$ destruction.

Table 5.9. Effect of Reactor Bank on Process Performance (Tests 1-3)

\begin{tabular}{|c|c|c|c|c|c|}
\hline \multirow[b]{2}{*}{$\begin{array}{c}\text { Test } \\
\text { Number }\end{array}$} & \multirow[b]{2}{*}{ Bank } & \multicolumn{2}{|c|}{ PCE } & \multicolumn{2}{|c|}{ TCE } \\
\hline & & PNL & WSRC & PNL & WSRC \\
\hline 1 & $\mathbf{A}$ & $69.5 \pm 6.8 \%$ & $74.7 \pm 3.1 \%$ & $\geq 99 \%$ & $\geq 99 \%$ \\
\hline 2 & B & $67.7 \pm 6.7 \%$ & $76.3 \pm 2.8 \%$ & $\geq 99 \%$ & $\geq 99 \%$ \\
\hline 3 & $\mathrm{C}$ & $68.2 \pm 3.0 \%$ & $73.4 \pm 3.1 \%$ & $\geq 99 \%$ & $\geq 99 \%$ \\
\hline
\end{tabular}

(a) Sampling port locations are indicated in flowsheet provided in Figure 4. 


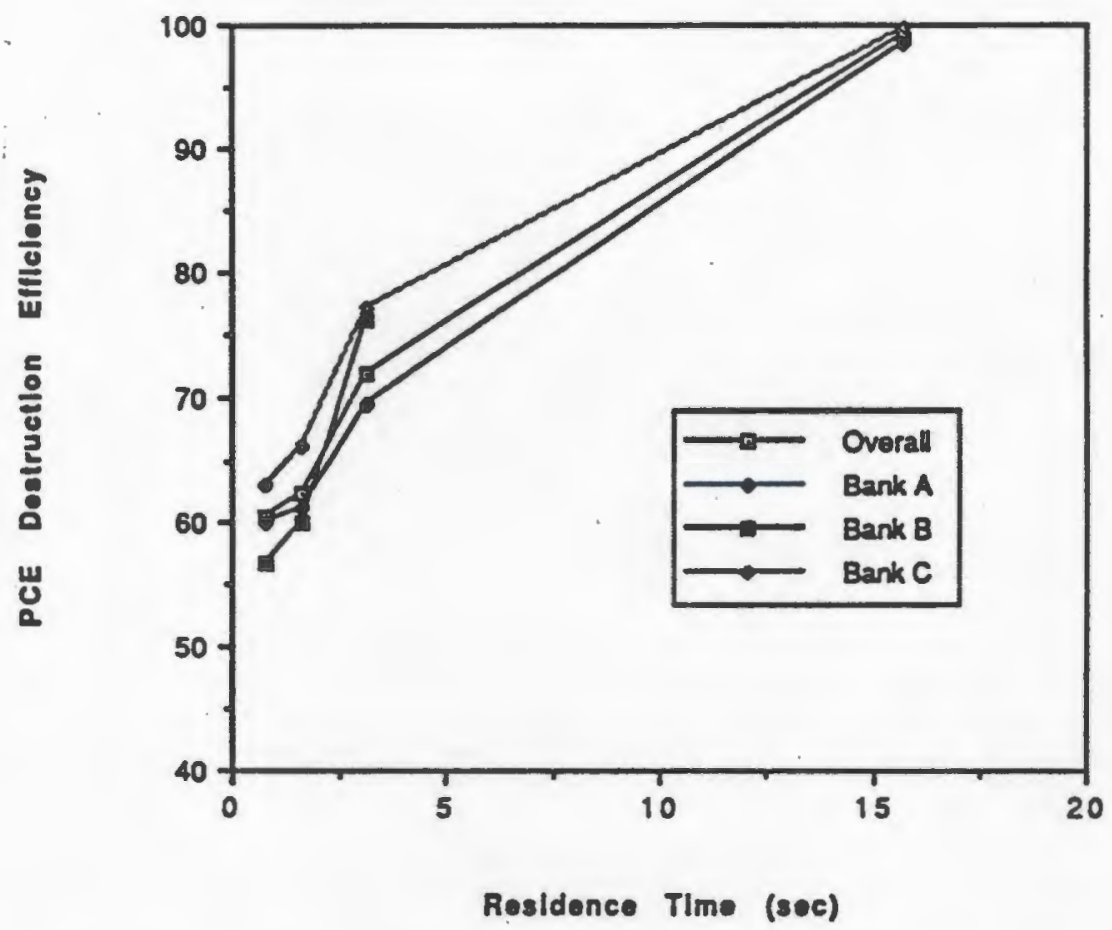

Figure 5.7. Effect of Reactor Bank on Perchloroethylene Destruction (Tests 4 through 7) 

- 


\subsection{Projected Treatment Costs in Comparison with Catalytic Oxidation}

Treatment costs are projected for a full-scale (300 to $500 \mathrm{~cm}$ ) HEC process for treating a relatively concentrated ( 3000 ppmv total) air stream contaminated with trichloroethylene and perchloroethylene in the same 3:17 ratio observed in the SRS soil offgas during the PNL field tests. The projected costs assume the use of a secondary wet scrubber to remove acid gases, consisting mainly of $\mathrm{HCl}$. It is also assumed that relatively low concentrations of partially reacted byproducts in the HEC-reactor effluent are mineralized by liquid-phase reactions occurring in the wet scrubber, ${ }^{\text {(a) }}$ enabling the process to meet clean-air requirements without generating a regulated secondary waste stream. The projected HEC treatment costs are then compared with baseline costs for catalytic oxidation as determined by conversations with a manufacturer of catalytic-oxidation equipment. The projected costs do not include labor charges, which would be assumed to be the same for both systems. A basis for labor charges is difficult to determine because both systems would be expected to operate substantially unattended with relatively low maintenance. A total downtime of $8 \%$, equivalent to one month/year, is assumed for both processes. For both processes, a unit cost for electricity of $\$ 0.05$ per $\mathbf{k W ~ h r}$ is used as a basis for calculating annual operating costs, based on the 30-year average cost of electricity as quoted by Westinghouse Hanford Company staff.

\subsection{Scaleup of HEC Reactor}

Assuming that the destruction of contaminant in a corona process can be described as a first-order reaction (Heath et al. 1992), the size of reactor required to treat a given offgas stream can be determined, provided kinetic data are available for that waste stream. The rate expression for a first-order kinetic decay is

$$
\ln \left(C_{0} / C\right)=k t
$$

where $\mathrm{C}_{0}$ and $\mathrm{C}$ are the inlet and outlet concentrations of the contaminant being destroyed, $\mathrm{t}$ is the reactor residence time in seconds, and $\mathbf{k}$ is the first-order rate constant in inverse seconds. For this analysis, field data on the destruction of PCE and TCE in the SRS soil offgas stream can be used to estimate destruction-rate constants for a first-order rate equation. Because the destruction of PCE was rate limiting, the most conservative approach would be to base equipment scaleup on the ability to destroy PCE. Using the first-order rate expression, the following rate constants are calculated based on the following destruction efficiencies for PCE that were measured at the following residence times:

- $\mathrm{k}=1.6 \mathrm{~s}^{-1}$ (for $73 \%$ destruction at a residence time of $0.8 \mathrm{~s}$ )

(a) The HEC effluent is known from unpublished laboratory work to contain strong oxidants, possibly including hydrogen peroxide, ozone, and hypochlorite ions. When the effluent is bubbled through water, dissolved compounds added to the water (including methylene blue and potassium iodide) are rapidly oxidized. 
- $k=0.9 \mathrm{~s}^{-1}$ (for $76 \%$ destruction at a residence time of $1.6 \mathrm{~s}$ )

- $\mathrm{k}=0.9 \mathrm{~s}^{-1}$ (for $94 \%$ destruction at a residence time of $3.1 \mathrm{~s}$ )

Of the calculated values, $\mathrm{k}=0.9 \mathrm{~s}^{-1}$ corresponds to the slowest rate of reaction. Using this value, a reactor residence time of $3.3 \mathrm{~s}$ would be required to achieve $95 \%$ destruction of PCE, corresponding to the level of cleanup required by current EPA regulations.

A treatment capacity of at least $50 \mathrm{cfm}$ is assumed to be required for each reactor in a full-scale HEC treatment process to keep the number of reactors (and associated costs) to a reasonable minimum. To achieve the calculated residence-time requirement of $3.3 \mathrm{~s}$ for $95 \%$ PCE destruction, a $50 \mathrm{cfm}$ reactor would require a packed-bed volume of $2.8 \mathrm{ft}^{3}$. This corresponds to a volumetric scaleup-factor of 21.3 over the pilot-scale HEC reactors that were used in the field demonstration. If the power-supply voltage used for the full-scale process is assumed to be kept at $30 \mathrm{kV}$, the same as the pilot-scale process, the dimensions of the required $50-\mathrm{cfm}$ reactor can be calculated. While no further details can be given at this time due to the proprietary nature of the HEC technology, it can be stated that the calculated dimensions would enable six 50-cfm reactors to be placed in roughly the same skid size used in the existing pilot-scale HEC process. At $30 \mathrm{kV}$, the power required per reactor is estimated as $15 \mathrm{~kW}$, based on power data obtained during the field demonstration.

Using a volumetric scaleup-factor of 21.3 , the installed cost of one full-scale (50-cfm) reactor can be estimated as $\$ 4.4 \mathrm{~K}$ based on the actual cost of the pilot-scale reactors, and assuming similar materials, fabrication and installation techniques. (The present HEC reactors were fabricated by WHC and assembled by PNL at a total cost of $\$ 1.4 \mathrm{~K}$ per reactor, including materials. For this analysis, it is assumed that an off-site fabricator would be able to supply the same reactors in quantity for half this cost. A published ${ }^{(a)}$ cost-scaling factor $(0.6)$ for general process equipment is then used to arrive at the per-reactor estimate of $\$ 4.4 \mathrm{~K}$.)

\subsection{Capital Costs for a Full-Scale HEC Process}

A typical corona process for treating contaminated soil offgases would consist of a vacuum blower followed by a multiple-reactor corona system, followed by a secondary scrubber. A blower capable of 300 -cfm operation is estimated to cost $\$ 14 \mathrm{~K} ; \$ 19 \mathrm{~K}$ for a 500 -cfm blower. A 300 -cfm process would require six full-scale HEC reactors at a cost of $\$ 26 \mathrm{~K}$ while a 500 -cfm process would require ten 50$\mathrm{cfm}$ reactors at a cost of $\$ 44 \mathrm{~K}$, based on projections made in section 6.1. The installed cost of a reactor skid with piping and process instrumentation for a six-reactor (300-cfm) HEC system would be expected to be $\$ 28 \mathrm{~K}$, based on the installed cost of the existing field skid. (The existing skid had an installed cost of $\$ 70 \mathrm{~K}$, but would be projected to cost $\$ 28 \mathrm{~K}$ if fabricated and installed by an off-site vendor.) The cost of a reactor skid with piping and process instrumentation for a 10-reactor (500-cfm) HEC system would be expected to be $\$ 38 \mathrm{~K}$, based on $\$ 28 \mathrm{~K}$ for a 300 -cfm skid, and a cost-scaling factor of 0.6 for general process equipment. ${ }^{(b)}$ The power supply required for a 300 -cfm HEC

(a) Peters and Timmerhaus, 1980.

(b) Peters and Timmerhaus, 1980. 
process, based on power data obtained during the field demonstration, would be a three-phase, $90-\mathrm{kW}$ supply capable of $30-\mathrm{kV}$ operation, at a vendor-quoted cost of $\$ 17 \mathrm{~K}$. A 500 -cfm process would require at $150-\mathrm{kW}$ supply at a vendor-quoted cost of $\$ 24 \mathrm{~K}$. The installed cost of a wet spray-scrubber sized to remove $\mathrm{HCl}$ from the effluents of the 300 - and $500-\mathrm{cm}$ HEC processes would be $\$ 14 \mathrm{~K}$ and $\$ 19 \mathrm{~K}$, respectively, based on historic vendor quotes. The cost of a 3,000-gal plastic storage tank to store the spent scrub solution for batch disposal would be $\$ 2 \mathrm{~K}$ for both HEC processes. These assumptions result in total costs for capital equipment of $\$ 101 \mathrm{~K}$ for a $300-\mathrm{cfm}$ HEC process and $\$ 146 \mathrm{~K}$ for a 500 -cfm HEC process. Assuming an interest rate of 5\% and a payback period of $5 \mathrm{yr}$, the annual costs for capital equipment would be $\$ 23 \mathrm{~K}$ and $\$ 34 \mathrm{~K}$, respectively for the 300 -cfm and 500-cfm HEC processes. Table 6.1 provides a summary of the HEC capital investment costs.

\subsection{Annual Costs for a Full-Scale HEC Process}

The cost for operating the proposed HEC process would involve mainly the electricity required to operate the process and the cost to handle and dispose of the scrub solution, which is assumed to consist of a neutral-pH, $<10 \mathrm{wt} \%$ solution of sodium chloride in water. The power associated with the $300-\mathrm{cfm}$ process is roughly $90 \mathrm{~kW}$, with a corresponding annual cost of $\$ 36 \mathrm{~K}$ assuming $24-\mathrm{h}$ operation with $8 \%$ downtime. Power costs for the $150-\mathrm{kW}, 500$-cfm process would be $\$ 60 \mathrm{~K}$ per year. For the $300-\mathrm{cfm}$ process, a 3000 -gal inventory of salt water would need to be disposed of every two years; for the 500-cfm process, one 3000-gal inventory every year. Because sodium chloride at $<10$ wt\% in water is a Class-D (unregulated) waste, it could be disposed of on site. The cost of disposal, including handling, chemical analyses, and record keeping, is expected to be no more than $\$ 10 \mathrm{~K}$ per 3000 -gal inventory. This results in yearly disposal costs of $\$ 6 \mathrm{~K}$ and $\$ 10 \mathrm{~K}$ for the 300 -cfm and 500-cfm processes, respectively. These assumptions result in annual operating costs of $\$ 42 \mathrm{~K}$ and $\$ 70 \mathrm{~K}$, respectively. The total annual costs are then projected at $\$ 65 \mathrm{~K}$ and $\$ 104 \mathrm{~K}$, respectively. The HEC annual operating and total annual costs are outlined in Table 6.2.

Table 6.1. Summary of HEC Capital Investment Costs

\begin{tabular}{|c|c|c|}
\hline $\begin{array}{l}\text { Capital Equipment } \\
\text { Purchase Cost }\end{array}$ & $\begin{array}{c}300 \text { SCF } \\
\text { M (\$) }\end{array}$ & $\begin{array}{c}500 \underset{(\$)}{\text { SCFM }} \\
\text { (\$) }\end{array}$ \\
\hline Blower & 14,000 & 19,000 \\
\hline Reactors & 26,000 & 44,000 \\
\hline Power Supply & 17,000 & 24,000 \\
\hline Process Skid & 28,000 & 38,000 \\
\hline Scrubber & 14,000 & 19,000 \\
\hline Storage Tank & 2,000 & 2,000 \\
\hline Total Capital Cost & 101,000 & 146,000 \\
\hline Annualized Capital (\$/yr) & 23,000 & 34,000 \\
\hline
\end{tabular}


Table 6.2. Summary of HEC Operating and Total Annual Costs

\begin{tabular}{|c|c|c|}
\hline $\begin{array}{l}\text { Process Operating } \\
\text { Costs }(\$ / y r)\end{array}$ & $\begin{array}{c}300 \underset{(\$)}{\text { SCFM }} \\
\text { (\$) }\end{array}$ & $\begin{array}{c}500 \underset{\text { SCFM }}{(\$)} \\
\text { S }\end{array}$ \\
\hline Power Costs & 36,000 & 60,000 \\
\hline Class D Disposal Costs & 6,000 & 10,000 \\
\hline Annual Operating Costs & 42,000 & 70,000 \\
\hline Total Annual Cost & 65,000 & 104,000 \\
\hline
\end{tabular}

\subsection{Capital Costs for a Full-Scale CO Process}

A typical catalytic-oxidation process for treating contaminated soil offgases would consist of a vacuum blower followed by an electric preheater, and a wet or dry scrubber to remove acid gases. The preheater is required to raise the air stream to 700 to $800^{\circ} \mathrm{F}$ before entering the catalyst bed. The installed cost of a CO process capable of treating 300 to $500 \mathrm{cfm}$ of soil offgas at total PCE/TCE concentrations not exceeding $1000 \mathrm{ppmv}$ would be $\$ 150 \mathrm{~K}$, based on a purchase cost of $\$ 120 \mathrm{~K}$ (including blower and electric preheater) and a $25 \%$ installation fee of $\$ 30 \mathrm{~K}$. The process blower would need to be capable of compressing a 500-cfm air stream to 7 psig (corresponding to the pressure drop across the catalyst bed.) The cost of the acid-gas scrubber is assumed to be the same as for the HEC process: $\$ 14 \mathrm{~K}$ for the 300 -cfm process and $\$ 19 \mathrm{~K}$ for the 500 -cfm case, with an additional $\$ 2 \mathrm{~K}$ for a plastic storage container (or other fixed cost.) These assumptions result in a total cost for capital equipment of $\$ 166 \mathrm{~K}$ for a 300 -cfm catalytic-oxidation process, and $\$ 171 \mathrm{~K}$ for a 500 -cfm catalytic-oxidation process. Annual costs for capital equipment, based on an interest rate of $5 \%$ and a payback period of 5 yr, would be $\$ 38.3 \mathrm{~K}$ for a 300 -cfm and $\$ 39.5 \mathrm{~K}$ for a 500 -cfm catalytic oxidation process. Catalytic oxidation capital investment costs are outlined in Table 6.3.

\subsection{Annual Costs for a Full-Scale CO Process}

The cost for operating the $\mathrm{CO}$ process would include the electricity required to operate the blower and preheater, the cost for annual replacement of the catalyst, and the cost to handle and dispose of the spent acid-gas scrub medium. The power associated with preheating a 300 -cfm stream is $300 \mathrm{~kW}$, with a corresponding annual cost of $\$ 121 \mathrm{~K}$ assuming 24-h operation with $8 \%$ downtime and no heat

Table 6.3. Summary of Catalytic Oxidation Capital Investment Costs

\begin{tabular}{|c|c|c|}
\hline $\begin{array}{l}\text { Capital Equipment } \\
\text { Purchase Cost }\end{array}$ & $\begin{array}{c}300 \text { SCFM } \\
(\$)\end{array}$ & $\begin{array}{c}500 \text { SCFM } \\
(\$)\end{array}$ \\
\hline Process Installed Cost & 150,000 & 150,000 \\
\hline Scrubber & 14,000 & 19,000 \\
\hline Storage Tank & 2,000 & 2,000 \\
\hline Total Capital Cost & 166,000 & 171,000 \\
\hline Annualized Capital (\$/yr) & 38,300 & 39,500 \\
\hline
\end{tabular}


recovery. The power associated with preheating for the 500 -cfm process is $500 \mathrm{~kW}$, with a corresponding annual cost of $\$ 201 \mathrm{~K}$. The power associated with operating the compressor would be $14 \mathrm{~kW}$ for the 300-cfm case and $23 \mathrm{~kW}$ for the 500 -cfm case, based on calculated values of pumping power, brake horsepower, and electromechanical conversion inefficiencies, resulting in additional annual energy costs of $\$ 5.6 \mathrm{~K}$ and $\$ 9.2 \mathrm{~K}$, respectively. Disposal of the acid-gas scrub medium would occur only once every three years due to dilution of the contaminant stream (as discussed below in Section 6.6), at a cost of $\$ 2 \mathrm{~K}$ per year for the 300-cfm case and $\$ 5 \mathrm{~K}$ per year for the 500 -cfm case. The amount of catalyst required would be $3 \mathrm{ft}^{3}$ for treating a 300 -cfm stream and $5 \mathrm{ft}^{3}$ for a 500 -cfm stream at a catalyst-cost of $\$ 4.5 \mathrm{~K}$ per $\mathrm{ft}^{3}$. The annual costs for catalyst replacement, assuming a $\$ 500 / \mathrm{ft}^{3}$ disposal fee, would be $\$ 13.5 \mathrm{~K}$ for the 300 -cfm process and $\$ 22.5 \mathrm{~K}$ for the 500 -cfm process. These assumptions result in total annual operating cost of $\$ 142 \mathrm{~K}$ and $\$ 237 \mathrm{~K}$, respectively, for the 300-cfm and $500-\mathrm{cfm}$ catalytic-oxidation processes. The total annual cost are then calculated as $\$ 180 \mathrm{~K}$ and $\$ 276.5 \mathrm{~K}$, respectively. Catalytic oxidation annual operating and total annual costs are summarized in Table 6.4.

\subsection{Comparison of Overall Treatment Costs for HEC and CO}

Overall treatment costs, in terms of the cost per pound of contaminant treated, depend on the mass flowrate of contaminants treated, and thus on the contaminant concentration for a given stream volume. Because of this, processes that can treat contaminants at higher concentrations can have a significant competitive edge over those that are restricted to treating dilute streams.

The total mass flowrate of contaminants associated with a 300-cfm stream contaminated with 3000 ppmv total of PCE and TCE (in a 17:3 ratio) is $166,000 \mathrm{lb}$ per year. For a 500 -cfm stream, the mass flowrate is $277,000 \mathrm{lb}$ per year. From this, overall treatment costs for the HEC and CO processes per pound of contaminant treated can be determined from the total annual equipment and operating costs calculated earlier.

For the High-Energy Corona process, an additional $25 \%$ contingency is added because of the large number of technical and cost assumptions associated with scaleup. The resulting final projected costs for the HEC technology are shown in Table 6.5. The projected cost for treating a more dilute stream

Table 6.4. Summary of Catalytic Oxidation Operating and Total Annual Costs

\begin{tabular}{lllll}
\multicolumn{1}{c}{$\begin{array}{c}\text { Process Operating } \\
\text { Costs }(\$ / y r)\end{array}$} & & 300 SCFM & & 500 SCFM \\
\cline { 1 - 1 } Preheater Energy & & $\$ 121,000$ & & $\$ 201,000$ \\
Blower Energy Duty & & $\$ 5,600$ & & $\$ 9,200$ \\
Catalyst Charge & & $\$ 13,500$ & & $\$ 22,500$ \\
Disposal Costs & & $\$ 2,000$ & & $\$ 5,000$ \\
Annual Operating Costs & & $\$ 142,000$ & & $\$ 237,000$ \\
Total Annual Cost & & $\$ 180,000$ & & $\$ 277,000$
\end{tabular}


Table 6.5. Comparison of Treatment Costs for HEC and Catalytic Oxidation

\begin{tabular}{|c|c|c|c|c|}
\hline \multirow{2}{*}{$\begin{array}{l}\text { Treatment } \\
\text { Technology }\end{array}$} & \multicolumn{2}{|c|}{300 CFM Inlet } & \multicolumn{2}{|c|}{500 CFM Inlet } \\
\hline & 1000 PPMV & 3000 PPMV & 1000 PPMV & 3000 PPMV \\
\hline High Energy Corona & $\$ 1.48 / \mathrm{lb}$ & $\$ 0.49 / \mathrm{lb}$ & $\$ 1.40 / \mathrm{lb}$ & $\$ 0.47 / 1 b$ \\
\hline Catalytic Oxidation & $\$ 3.40 / 1 b$ & $\$ 3.40 / 1 b^{(a)}$ & $\$ 3.14 / 1 b$ & $\$ 3.14 / \mathrm{lb}^{(\mathrm{a})}$ \\
\hline
\end{tabular}

(a) Catalytic Oxidation Systems do not operate above 1000 ppmv. Therefore, treatment of a 3000 ppmv stream would require a $2: 1$ dilution resulting in roughly the same operating and capital costs as treatment at 1000 ppmv.

with a total contaminant loading of $1000 \mathrm{ppmv}$ are also given, illustrating the effect of contaminant concentration on treatment cost. (The annual mass-treatment rates associated with a 1000-ppmv stream are $55,500 \mathrm{lb}$ and $92,500 \mathrm{lb}$, respectively for treatment at 300 and $500 \mathrm{cfm}$.)

Based on discussions with a vendor for $\mathrm{CO}$ equipment, the maximum concentration of chlorinated compounds that can be treated using the system described in Section 6.4 is 1000 ppmv. However, the assumed stream concentration for this cost analysis is $3000 \mathrm{ppmv}$. To treat this stream using $\mathrm{CO}$, the concentrated offgas removed from the soil would have to be diluted with two equal parts of ambient air at the compressor inlet to reduce the inlet concentration to the catalyst bed to $1000 \mathrm{ppmv}$ total of TCE and PCE. As a result, for the baseline 300 and 500-cfm treatment scenarios, the actual volume of soil offgas treated would be 100 and $167 \mathrm{cfm}$, respectively. At inlet concentrations of $1000 \mathrm{ppmv}$, this results in a total mass-treatment rates of 55,500 and 92,500 lb per year. Because of this, the annual costs for treating a more dilute stream (at $1000 \mathrm{ppmv}$ ) would be roughly identical, because the inlet stream volume and mass flowrate of contaminants would be the same for the diluted 3000 -ppmv stream. 


\subsection{References}

Birmingham, J. G. and R. R. Moore. 1990. "Reactive Bed Air Purification," U.S. Patent No. $4,954,320$.

Heath, W. O. 1992. "Investigations of Electric Fields for Low-Temprature Treatment of Soils and Liquids," in Proceedings of EPA/A\&WMA International Symposium, pp 428-447, Pacific Northwest Laboratory, Richland, Washington.

Heath, W. O., J. V. Virden, and T. M. Bergsman. 1993. "Method and Appartus for Chemically Altering Fluids in Continuous Flow," U.S. Patent No. 5,254,231.

Nunez, C. M., and G. H. Ramsey. 1993. "Corona Destruction: An Innovative Control Technology for VOCs and Air Toxics," Air and Waste, Vol. 43.

Peters, M. S., and K. D. Timmerhaus. 1980. Plant Design and Economics for Chemical Engineers, 3rd Edition, MeGraw-Hill, New York, New York.

Virden, J. W., W. O. Heath, S. C. Goheen, M. C. Miller, G. M. Mong, and R. L. Richardson. 1992. High-Energy Corona for Destruction of Vlatile Organic Compounds in Process Off-Gases, Vol. 1 Nuclear and Hazardous Waste Management, DOE Spectrum.

Yamamoto, T., and K. Ramanathan. 1992. "Control of Volatile Organic Compounds by an AC Energized Ferroelectric Packed Bed Reactor," IEEE Transactions on Industry Appl., Vol. 28, No. 3. 


\section{Distribution}

No. of

Copies

\section{OFFSITE}

2 DOE/Office of Scientific and Technical Information

3 Westinghouse Savannah River Company Building 773-42A

Aiken, SC 29808

Attn: J. S. Haselow

T. R. Jarosch

B. Looney

\section{ONSITE}

3 Westinghouse Hanford Company
C. H. Kindle, H6-05
G. C. Henckel, H6-04
V. J. Rohay, H6-06

55 Pacific Northwest Laboratory

C. R. Allen, P8-53

S. E. Barlow, K2-14

J. B. Birmingham, P7-41

R. A. Brouns, P7-41
No. of

Copies

T. M. Brouns, K9-08

H. C. Burkholder, K8-58

T. M. Bergsman, P7-41

W. O. Heath, P7-14 (15)

(10 Color)

B. D. Lerner, P8-08

D. L. Lessor, K7-15

G. M. Mong, P8-08

A. J. Peurrung, P8-01

L. M. Peurrung, P7-35

G. Pillay, P7-41

T. M. Orlando, K2-14

R. R. Shah, P7-41 (15) (8 Color)

S. C. Slate, K9-14

R. G. Tonkyn, K2-14

A. Y. Tonkovich, P8-38

J. W. Virden, K2-44

T. L. Walton, K9-08

Publishing Coordination

Technical Report Files (5)

Distr.1 
